\title{
UČINKOVITO UPRAVLJANJE U KONCERNU
}

Doc. dr. sc. Antun Bilić*

Prof. dr. sc. Siniša Petrović**

\author{
UDK: 347.72 \\ https://doi.org/10.30925/zpfsr.39.4.7 \\ Ur.: 3. rujna 2018. \\ Pr.: 15. listopada 2018. \\ Izvorni znanstveni rad
}

\section{Sažetak}

Rad razmatra modalitete učinkovitog upravljanja u različitim oblicima koncerna. Definicija koncerna, kao skup društava objedinjenih jedinstvenim vođenjem, podrazumijeva određeni stupanj integracije upravljanja. S druge strane, okolnost da svako od društava zadržava vlastitu pravnu osobnost sugerira barem djelomičnu upravljačku samostalnost. Granice međusobnog utjecaja društava koncerna su, dakle, određene suprotstavljenim centrifugalnim i centripetalnim silama. Na pravu povezanih društava je da jasno definira te granice i stavi ih na raspolaganje poduzetnicima da ih najbolje iskoriste prema svojim potrebama. Kao što će se pokazati takve granice nisu iste za sve vrste koncerna. U radu se detaljnije razmatraju tri oblika koncerna vladajućeg $i$ ovisnog društva - ugovorni koncern, koncern priključenih društava i faktični koncern.

Ključne riječi: učinkovito upravljanje; uprava; ugovorni koncern; koncern priključenih društava; faktični koncern; vladajuće i ovisno društvo.

* Dr. sc. Antun Bilić, docent, Sveučilište u Zagrebu, Pravni fakultet; abilic@pravo.hr.

** Dr. sc. Siniša Petrović, redoviti profesor u trajnom zvanju, Sveučilište u Zagrebu, Pravni fakultet; sinisa.petrovic@pravo.hr.

Ovaj je rad izrađen uz potporu Hrvatske zaklade za znanost, projekt br. 9366 "Pravni aspekti korporativnih akvizicija i restrukturiranje društava utemeljenih na znanju" i Sveučilišta u Rijeci, projekt br. 13.08.1.2.01 "Zaštita korisnika na hrvatskom i europskom tržištu financijskih usluga". 


\section{1. $U$ VOD}

Koncern je skup dvaju ili više društava objedinjenih jedinstvenim, odnosno zajedničkim vođenjem (čl. 476. Zakon o trgovačkim društvima, dalje: $\left.Z_{T}{ }^{1}\right)^{2}{ }^{2}$ Jedinstveno vođenje podrazumijeva da se društva koncerna vode kao gospodarski jedinstvena cjelina (uži pojam koncerna) ili barem kao gospodarsko jedinstvo neke od temeljnih poduzetničkih djelatnosti (širi pojam koncerna). ${ }^{3}$ Okolnost da su društva koncerna objedinjena jedinstvenim vođenjem sugerira da se društvima koncerna upravlja kao da je riječ o jednom jedinom društvu. Svako od društava koncerna zadržava, međutim, vlastitu pravnu osobnost. ${ }^{4}$ Drugim riječima, svako od društava koncerna ima svoju imovinu s kojom odgovara svojim vjerovnicima. Između koncerna kao jedinstveno vođene cjeline i odvojenih pravnih osobnosti pojedinih društava nužno postoji određena napetost pa čak i proturječje. ${ }^{5}$ Slikovito govoreći, upravljanje koncernom se nalazi pod pritiskom suprotstavljenih centrifugalnih i centripetalnih sila. Iz toga proizlazi temeljno pitanje ovoga rada - što znači da se koncernom učinkovito upravlja?

Pod pojmom upravljanja u ovom se radu u prvom redu razmatra vođenje poslova i vođenje društva, dakle aktivnost uprave ili upravnog odbora i izvršnih direktora (čl. 240. st. 1., čl. 272.h st. 1., čl. 272.1 st. 2. ZTD). U širem smislu upravljanje obuhvaća i upravljačke aktivnosti ostalih organa, nadzornog odbora pa i glavne skupštine, kroz koju članovi ostvaruju svoja upravljačka prava). ${ }^{6}$

Na prvi pogled se može činiti da je učinkovitost upravljanja gospodarski pojam, kojim se određuje sposobnost koncerna za ostvarivanjem dobiti i koje uopće nije nužno pravno uobličiti. Pravni aspekt učinkovitosti postaje vidljiv kad se postavi pitanje iz čije je perspektive upravljanje učinkovito? Odvojene pravne osobnosti društava koncerna znače da se učinkovitost, odnosno sposobnost ostvarivanja dobiti mora procjenjivati za svako od društava zasebno. Ono što je učinkovito iz perspektive vladajućeg društva ne mora biti učinkovito iz perspektive ovisnoga društva i obrnuto. Pravni aspekt učinkovitosti upravljanja se, dakle, sastoji u uspostavljanju pravila

$1 \quad \mathrm{NN}$ br. 111/93, 34/99, 121/99, 52/00, 118/03, 107/07, 146/08, 137/09, 125/11, 111/12, 68/13 i $110 / 15$.

2 Tako i § 18 njemačkoga AktG.

3 Barbić, J., Pravo društava, Knjiga prva, Opći dio, Zagreb, Organizator, 2008., str. 649; Koch, J. u: Hüffer, U.; Koch, J. (ur.), Aktiengesetz, München, C. H. Beck, 2015., § 18, para. 8-19; Bayer, W. u: Goette, W.; Habersack, M. (ur.), Münchener Kommentar zum Aktienrecht, Band 1, München, C. H. Beck, 2016., § 18, para. 29-30; Emmerich, V., u: Emmerich, V.; Habersack, M.; Schürnbrand, J. (ur.), Aktien- und GmbH-Konzernrecht, München, C. H. Beck, 2016., § 18, para. 10-11.

4 Čl. 473. st. 1. ZTD, za sudsku praksu v. VSRH Revt 60/04-2 od 6.10.2004.; VSRH Revr 344/082 od 17.6.2009.; VSRH Revt 159/11-2 od 24.1.2012.; VTS Pž-1934/06-3 od 22.4.2009.

5 Barbić, J., Opći dio, op. cit. u bilj. 3, str. 636-637; Altmeppen, H. u: Goette, W.; Habersack, M. (ur.), Münchener Kommentar zum Aktienrecht, Band 5, München, C. H. Beck/Franz Vahlen, 2015., § 311, para. 22 i dalje.

6 V. Barbić, J., Vođenje poslova i upravljanje u trgovačkim društvima (povezana društva), Hrvatska gospodarska revija, vol. 45, 11/1996, str. 1574-1582, kao i Wiesner, G. u: HoffmannBecking, M. (ur.), Münchener Handbuch des Gesellschaftsrechts, Band IV, München, C. H. Beck, 2015, § 19, para. 1 i dalje. 
do koje razine zajednička tržišna strategija mora uzeti u obzir odvojene pravne osobnosti društva koncerna. Pitanje učinkovitosti tako se postavlja kao pitanje granica učinkovitosti jednih društava na račun drugih.

Cilj je ovog rada, dakle, objasniti mogućnosti i granice učinkovitog upravljanja društvima u sastavu koncerna. Iz toga će se izvesti zaključci u kojim je situacijama koncern optimalan oblik poslovanja, a kada je preporučljivije poslovati putem jednoga jedinog društva. Koncern sa značajnijim stupnjem sudjelovanja vladajućeg društva u ovisnim društvima, s preko tri četvrtine temeljnoga kapitala bi se, naime, lako mogao preobraziti u jedno jedino društvo putem statusnih promjena pripajanja ili spajanja (čl. 512. i dalje ZTD). Zbog toga se većina pripajanja i spajanja odvija upravo između društava koncerna. ${ }^{7}$

Pri izvođenju zaključaka rad polazi od analize odredaba ZTD-a o granicama utjecaja u koncernu. Ta su pravila, osobito u slučaju faktičnoga koncerna, međutim, neodvojiva od općih pravila prava društava o korporativnom upravljanju društvima kapitala. ${ }^{8}$ Pravila i načela korporativnog upravljanja, naime, ovisno o tomu o kojem je društvu riječ (dioničkom društvu ili društvu s ograničenom odgovornošću) su više ili manje kogentna i postojanje koncerna ne smije dovesti do toga da se gube granice ovlasti (a slijedom toga i odgovornosti) pojedinih organa društava. To nije puko formalno pitanje, nego pravila korporativnog upravljanja i odnosi koji se njima uspostavljaju između organa društva teže tomu da se upravo njihovim poštivanjem postignu optimalni preduvjeti za uspješno i učinkovito upravljanje društvom. Kako u koncernu postoji navedeni koncept zajedničkog vođenja društava koja čine koncern, a koji je nesumnjivo ekonomski opravdan i racionalan, ključno je pitanje kako postaviti ravnotežu između potrebe da se više društava ,jedinstveno (objedinjeno) vodi“, a da pritom svako društvo ne samo formalno, nego i suštinski zadrži samostalnost u odlučivanju, u skladu s pravilima korporativnog upravljanja društva nekoga pravnog oblika. Zbog toga će se puno pažnje posvetiti pravilima o vođenju poslova dioničkog društva i društva s ograničenom odgovornošću.

Rad uzima u obzir i sudsku praksu hrvatskih sudova. ${ }^{9}$ Nažalost, dostupna sudska praksa se ne dotiče izravno upravljanja koncernom. Relativno mali broj presuda koji govori o povezanim društvima uglavnom se bavi pitanjem odgovornosti društava za obveze drugih društava. ${ }^{10}$ Rad uzima u obzir i postojeću hrvatsku znanstvenu i stručnu literaturu o povezanim društvima koja o koncernu najčešće govori općenito, bez posebnog izdvajanja problema učinkovitog upravljanja. ${ }^{11}$

7 Stengel, A. u: Semmler, J; Stengel, A. (ur.), Umwandlungsgesetz, München, C. H. Beck, 2017, $\S 2$, para. 20.

8 Barbić, J., Opći dio, op. cit. u bilj. 3, str. 637.

9 Riječ je o ukupnoj sudskoj praksi koja je objavljena na mrežnim stranicama Vrhovnoga suda i portala IUSinfo.

10 Osobito u kontekstu proboja pravne osobnosti, v. VSRH Revt 159/11-2 od 24.1.2012., VSRH Revt 60/04-2 od 6.10.2004.; VTS Pž-1760/02 od 15.4.2003. (sentenca na IUSinfo); VTS Pž 2859/04-3 od 6.11.2007.; VTS Pž 7222/04-3 od 11.10.2005.; VTS Pž 6097/05-3 od 29.5.2007.).

11 O upravljanju koncernom se osobito govori u: Barbić, J., Vođenje poslova i upravljanje, op. cit. u bilj. 6. Općenito o koncernu: Barbić, J., Opći dio, op. cit. u bilj. 3, str. 633-673; Barbić, J., Koncern i društva koncerna, Pravo u gospodarstvu, vol. 46, 4/2007, str. 57-94; Gorenc, V., Povezana društva prema Zakonu o trgovačkim društvima, Računovodstvo, revizija i financije, 
Rad se uvelike oslanja i na izvore njemačkoga prava imajući u vidu da je hrvatsko pravo povezanih društava izravno inspirirano njemačkim rješenjima. Većina odredbi ZTD-a o povezanim društvima imaju, naime, izravni predložak u pravilima njemačkoga Zakona o dioničkim društvima (Aktiengesetz). ${ }^{12}$

Rad prvo objašnjava polje primjene odredaba o učinkovitom upravljanju koncernom, osobito s obzirom na ostala povezana društva i eventualni vladajući položaj fizičkih osoba (2.). Nakon toga će se objasniti mogućnosti učinkovitog upravljanja ugovornim koncernom (3.) i koncernom priključenjem (4.). Središnji dio rada će posvetiti svoju pozornost učinkovitom upravljanju u faktičnom koncernu, pri čemu će se ukazati na razlike između dioničkih društava i društava s ograničenom odgovornošću (5.). Naposljetku će se donijeti zaključci, s osobitim naglaskom na eventualne prednosti i mane koncerna u odnosu na jedinstveno društvo nastalo statusnom promjenom pripajanja ili spajanja (6.).

\section{NA KOGA SE SVE PRIMJENJUJU PRAVILA O UČINKOVITOM UPRAVLJANJU POVEZANIH DRUS̆TAVA?}

Pravo povezanih društava poznaje više vrsta koncerna, ovisno o tomu na koji se način provodi jedinstveno upravljanje. Tako postoji koncern vladajućeg i ovisnog društva (čl. 476. st. 1. ZTD) i, u praksi puno rjeđi, koncern ravnopravnih društava (čl. 476. st. 2. ZTD). Koncern vladajućeg i ovisnog društva se može podijeliti na ugovorni koncern, koncern priključenjem i faktični koncern. Zakon postavlja neoborivu pretpostavku da sklapanjem poduzetničkog ugovora o vođenju poslova društva nastaje ugovorni koncern, kao i da priključenjem društava nastaje koncern priključenjem (čl. 476. ZTD). Faktični koncern je otvorena kategoriju koja obuhvaća sve oblike jedinstvenog upravljanja koji se ne mogu podvesti pod ugovorni koncern ili koncern

vol. 4, 10/1994, str. 1786-1797; Ledić, D., Povezana društva - začetak hrvatskog prava koncerna, Zbornik Pravnog fakulteta Sveučilišta u Rijeci, vol. 16, 1/1995, str. 37-51 O nekim posebnim pitanjima koncerna v. Ceronja, P., O odgovornosti članova nadzornog odbora ovisnog društva za štetu zbog povrede obveze nadzora tražbina iz ugovora o zajmu sklopljenih između ovisnog i vladajućeg društva, Pravo u gospodarstvu, vol. 50, 5/2011, str. 1158-1176; Cindori, V., Izvješće o ovisnosti trgovačkih društava s aspekta poslovanja društava, Informator, 5436/2006, str. 6-8; Jurić, D., Odgovornost vladajućeg društva za obveze ovisnog društva u hrvatskom i usporednom pravu, Zbornik Pravnog fakulteta Sveučilišta u Rijeci, vol. 23, 2/2002, str. 507-540; Jurić, D., Transparentnost statusnih i financijskih odnosa povezanih društava, Zbornik Pravnog fakulteta Sveučilišta u Rijeci, vol. 27, 2/2006, str. 939-984; Braut Filipović, M., Odgovornost društva majke za obveze društva kćeri, Zbornik Pravnog fakulteta Sveučilišta u Rijeci, vol. 32, 2/2011, str. 795-828; Moslavac, B., Pitanje odgovornosti u slučaju ovisnosti društva kada nema ugovora o vođenju poslova društva, Informator, vol. 56, 5695-5696/2008, str. 5-7; Vidović, A., Koncern - aktualna pitanja povezivanja društava, Računovodstvo, revizija i financije, vol.18, 3/2008, str. 194-195. O upravljanju koncernom bilo je govora i u ranijem radu autora ovoga članka, čija je glavna tema odgovornost članova organa u društvima koncerna, v. Bilić, A.; Petrović, S., Odgovornost članova društava u faktičnom koncernu, Zbornik Pravnog fakulteta Sveučilišta $u$ Rijeci, vol. 39, 2002., br. 2, str. 727-751. 
priključenjem. ${ }^{13}$ Tako apstraktna definicija faktičnoga koncerna konkretizirana je oborivom presumpcijom da vladajuće i ovisno društvo čine koncern (čl. 476. st. 1. ZTD). Odnos vladajućeg i ovisnog društva postoji na temelju posredno ili neposredno prevladavajućeg utjecaja koji vladajuće društvo može imati u ovisnome društvu (čl. 475. st. 1. ZTD). Nije, dakle, nužno da prevladavajući utjecaj stvarno postoji, nego je dovoljno da vladajuće društvo ima mehanizme kojima bi takav utjecaj moglo vršiti, primjerice da može poduzimati mjere protiv ovisnoga društva ili osoba koje u njemu vode poslove.$^{14}$ Dokazivanje prevladavajućeg utjecaja se, osim toga, olakšava oborivom presumpcijom prema kojoj je društvo koje ima većinu udjela u temeljnom kapitalu u nekom društvu ili većinu prava glasa u tome društvu, vladajuće u odnosu na to društvo (tzv. većinsko sudjelovanje čl. 475. st. 2., čl. 474. ZTD).

Ovaj će rad razmotriti učinkovito upravljanje u svim oblicima koncerna vladajućeg i ovisnoga društva. Rad se neće baviti koncernom ravnopravnih društava, zbog toga što je on u praksi manje zastupljen i zbog toga što počiva na bitno drukčijim odnosima moći.

Koncern je, međutim, samo jedan od više pojavnih oblika povezanih društava. Ostali su oblici društva s većinskim sudjelovanjem, vladajuće i ovisno društvo, društva s međusobnim udjelima i društva povezana poduzetničkim ugovorima (čl. 473. ZTD). Kao što je već rečeno, glavna funkcija društava s većinskim sudjelovanjem te vladajućeg i ovisnog društva je stvoriti oborivu presumpciju da postoji faktični koncern. Za oblike povezanih društava koji ne dovode do nastanka koncerna nije, međutim, moguće govoriti o učinkovitom upravljanju u smislu ovoga rada. Za koncern je, naime, svojstveno upravo jedinstveno upravljanje (čl. 476. ZTD), odnosno okolnost da ne postoji koncern znači da se povezanim društvima ne upravlja jedinstveno. Ako ne postoji jedinstveno upravljanje ne može se ni govoriti o njegovoj učinkovitosti. Iako se može govoriti o učinkovitom upravljanju svakoga od više povezanih društava, to se ne razlikuje od pitanja učinkovitog upravljanja bilo kojega pojedinačnog društva i, kao takvo, nije osobitost prava povezanih društava.

Koncern, kao i ostali oblici povezanih društava, podrazumijevaju da se radi o više društava, neovisno je li riječ o društvima osoba ili društvima kapitala. ${ }^{15} \mathrm{~A}$ contrario to bi značilo da se pravila o povezanim društvima ne mogu primjenjivati na fizičke osobe pa ni one koje se bave gospodarskom djelatnošću. Ipak, ne smije se smetnuti s uma da i fizičke osobe mogu biti povezane s trgovačkim društvima na isti način na koji mogu biti povezana i druga društva. Očito je, primjerice, da i fizička osoba može imati većinu udjela ili većinsko pravo odlučivanja u pojedinom društvu i da na taj ili drugi način, može predstavljati vladajuću osobu. Jednako tako, trgovac fizička osoba bi mogao jedinstveno voditi svoje poduzeće i poduzeće društva u kojemu ima prevladavajući utjecaj. Zbog toga se postavlja pitanje ne bi li se pravila o povezanim društvima pa tako i pravila o učinkovitom upravljanju koncernom mogla na odgovarajući način primjenjivati i na fizičke osobe, u najmanju ruku fizičke osobe

13 Barbić, J., Opći dio, op. cit. u bilj. 3, str. 650-651.

14 VTS Pž 3289/2017-2 od 29.5.2017.; Barbić, J., Opći dio, op. cit. u bilj. 3, str. 643-644; Bayer, W., op. cit. u bilj. 3, § 17, para. 11.

15 Barbić, J., Opći dio, op. cit. u bilj. 3, str. 634, 637. 
koje su trgovci. U prilog takvoj primjeni govorilo bi ustavno načelo prema kojemu država osigurava svim poduzetnicima jednak položaj na tržištu (čl. 49. st. 2. Ustava Republike Hrvatske $\left.{ }^{16}\right) .{ }^{17}$ Drugim riječima, dok god zakon vladajućim društvima postavlja ograničenja ili im daje određene povlastice, jednaka ograničenja i povlastice morao bi pružiti fizičkim osobama koje se nalaze u usporedivom položaju.

Usporedbe radi, njemačko pravo povezanih društava ne govori o društvima nego o poduzećima (Unternehmen). ${ }^{18} \mathrm{U}$ tom specifičnom kontekstu pojam poduzeća ne označava, kao obično, gospodarsku cjelinu kao objekt pravnog prometa ${ }^{19}$ nego pravni subjekt, adresata pravne norme, koji se bavi gospodarskom djelatnošću neovisno o sudjelovanju u povezanom društvu. ${ }^{20}$ Izraz ,poduzeće“ odabran se upravo zbog toga da bi ista rješenja mogla vrijediti za funkcionalno istovjetne pravne oblike pa i za fizičke osobe. ${ }^{21}$ Bavljenje gospodarskom djelatnošću nužna je pretpostavka jer je jedna od najvažnijih funkcija pravila o povezanim društvima zaštita od opasnosti da će član društva, koji se i sam bavi gospodarskom djelatnošću, prisiliti ovisno društvo da djeluje u njegovu, a ne vlastitom gospodarskom interesu. ${ }^{22} \mathrm{Za}$ rješavanje eventualnog sukoba interesa članova društva koji se ne bave gospodarskom djelatnošću dostaju opća pravila prava društava. Zbog toga se „poduzećem“ mogu smatrati samo one fizičke osobe koje su trgovci neovisno o svojem sudjelovanju u povezanom društvu, kao i fizičke osobe koje znatno sudjeluju u nekom drugom društvu, najčešće većinom udjela ili većinskim pravom odlučivanja. ${ }^{23}$

S obzirom na prednosti koje nudi njemačko rješenje, kao i okolnost da hrvatsko pravo društava u drugim pogledima vjerno slijedi njemački predložak, trebalo bi preporučiti da se pojam „društva“ u smislu pravila ZTD-a o povezanim društvima, teleološki protumači na način da obuhvati i poduzetnike fizičke osobe te fizičke osobe $\mathrm{S}$ većinskim sudjelovanjem $\mathrm{u}$ nekom drugom društvu. ${ }^{24}$ Takvo široko tumačenje riječi ,društvo“" ne bi trebalo smatrati contra legem. Kod ugovora o vođenju poslova, čl. 494. st. 1. ZTD, primjerice, spominje da vladajuće društvo može biti i trgovac pojedinac. ${ }^{25}$ Slično tomu, opće odredbe ZTD-a o sjedištu i predmetu poslovanja govore samo o sjedištu trgovačkog društva (čl. 32-40. ZTD), iako se iz okolnosti da trgovac pojedinac također ima registrirano sjedište i predmet poslovanja (čl. 3. st. 3. ZTD) može zaključiti da se i na njega primjenjuju spomenute odredbe. Neovisno o tomu, moglo bi se razmisliti i o eventualnoj izmjeni ZTD-a, kojom bi se pojam društva u kontekstu povezanih društava zamijenio pojmom poduzetnika ili nekim

16 NN br. 56/1990, 135/1997, 113/2000, 28/2001, 76/2010, 5/2014.

17 V. i Bilić, A.; Petrović, S., op. cit. u bilj. 11, str. 735.

$18 \S 15 \mathrm{AktG}$ i dalje.

19 Za pojam koncerna u tom smislu v. Barbić, J., Opći dio, op. cit. u bilj. 3, str. 223.

20 Koch, J., op. cit. u bilj. 3, § 15, para. 9; Bayer, W., op. cit. u bilj. 3, § 15, para. 9.

21 Emmerich, V., Habersack, M., Konzernrecht, München, C. H. Beck, 2008., § 2, para. 9; Koch, J., op. cit. u bilj. 3, § 15, para. 8, 10.

22 Emmerich, V., Habersack, H., op. cit. u bilj. 21, § 2, para. 6; Bayer, W., op. cit. u bilj. 3, § 15, para. 7; Koch, J., op. cit. u bilj. 3 , § 15, para. 10.

23 Emmerich, V., Habersack, H., op. cit. u bilj. 21, § 2, para. 11-12; Koch, J., op. cit. u bilj. 3, § 15, para. 11.

24 Slično Cindori, op. cit. u bilj. 11, str. 6.

25 Tako i Barbić, J., Opći dio, op. cit. u bilj. 3, str. 695. 
odgovarajućim terminom.

Za potrebe ovog rada, široko tumačenje pojma „društvo“ značilo bi da se daljnja izlaganja o učinkovitom upravljanju u koncernu na odgovarajući način mogu primijeniti i na situaciju kada poduzetnik fizička osoba ima vladajući položaj u nekom društvu. Po naravi stvari fizička osoba se ne bi mogla nalaziti u odnosu ovisnosti. Ovisnost u smislu prava povezanih društava, naime, može nastati samo na temelju korporativnoga statusnog prava, dakle većinom udjela, većinskim pravom odlučivanja ili organizacijskim poduzetničkim ugovorom. ${ }^{26} \mathrm{Ne}$ bi dostajala puka ovisnost na temelju obveznopravnog ugovora, primjerice, na temelju ugovora o kreditu, koliko god bi takav ugovor bio važan njegovom korisniku. ${ }^{27}$ Podrazumijeva se da u fizičkoj osobi nije moguće imati većinu udjela ili većinsko pravo odlučivanja. Jednako tako, fizička osoba ne može se obvezati poduzetničkim ugovorima, jer to mogu samo društva kapitala (čl. 479., 480. ZTD). ${ }^{28}$

\section{UČINKOVITO UPRAVLJANJE UGOVORNIM KONCERNOM}

Ugovor o vođenju poslova društva, kojim nastaje ugovorni koncern (čl. 476. st. 1. ZTD), zakon određuje kao ugovor kojim društvo kapitala podvrgava vođenje poslova društva drugome društvu (čl. 479. st. 1. ZTD). Već iz zakonske definicije je, dakle, jasno da je vladajuće društvo ovlašteno objediniti upravljanje vlastitim i ovisnim društvom. To je iznimka od općeg pravila prema kojemu svako društvo treba voditi prema njegovim vlastitim interesima. Time se relativiziraju granice među odvojenim pravnim osobnostima društava koncerna. Ključno je utvrditi koje su granice te relativizacije, odnosno u kojoj mjeri ovisno društvo zadržava upravljačku samostalnost.

Odgovor se može izvesti iz čl. 493. ZTD prema kojem je vladajuće društvo ovlašteno upravi, odnosno izvršnim direktorima ovisnoga društva davati upute glede vođenja poslova društva makar te upute bile i štetne po ovisno društvo (čl. 493. st. 1. ZTD), a uprava, odnosno izvršni direktori ovisnoga društva moraju slijediti takve upute vladajućega društva (čl. 493. st. 2. ZTD). Iz toga se mogu izvući četiri zaključka. Prvi je da vladajuće društvo može odlučujuće utjecati na upravu društva (ili izvršne direktore) ovisnoga putem obvezujućih uputa. To se razlikuje od općeg pravila dioničkih društava prema kojemu je uprava svakog društva dužna voditi poslove društva na vlastitu odgovornost (čl. 242. ZTD), nezavisno o uputama glavne skupštine i nadzornog odbora. Uprava ovisnoga društva, dapače, mora slijediti i upute koje su za ovisno društvo štetne. Kada bi ovisno društvo bilo ovlašteno odbiti štetne upute ne bi se ni moglo govoriti o ,podvrgavanju vođenja poslova““. ${ }^{29}$

Mogućnost centraliziranog upravljanja stavlja članove i vjerovnike ovisnoga društva u nepovoljan položaj. Zbog toga zakon predviđa različite mehanizme kojima

26 Barbić, J., Opći dio, op. cit. u bilj. 3, str. 644; Emmerich, V., Habersack, H., op. cit. u bilj. 21, § 3, para. 21.

27 Barbić, J., Opći dio, op. cit. u bilj. 3, str. 644; Bayer, W., op. cit. u bilj. 3, § 17, para. 29.

28 Tako i njemačko pravo, $\S 291,292$ AktG.

29 Slično i Barbić, J., Opći dio, op. cit. u bilj. 3, str. 714, koji govori da je to bit toga ugovora. 
nastoji poboljšati njihov položaj. Kao prvo, zakon postavlja zahtjevne pretpostavke za sklapanje ugovora o vođenju poslova društva. Uprava ovisnoga društva tako mora u pisanom izvješću obrazložiti razloge za sklapanje poduzetničkog ugovora i njegov sadržaj (čl. 481. st. 4. ZTD), poduzetnički ugovor moraju pregledati revizori i o tomu izraditi pisano mišljenje (čl. 481.a ZTD), za sklapanje ugovora nužna je suglasnost skupštine ovisnoga društva glasovima koji predstavljaju najmanje tri četvrtine temeljnoga kapitala zastupljenog na skupštini društva (čl. 481. st. 1. ZTD), a ugovor stupa na snagu tek nakon što se upiše u sudski registar (čl. 482. st. 2. ZTD). Vjerovnici ovisnoga društva osobito su zaštićeni pravilima o izdvajanju u zakonske rezerve ovisnoga društva (čl. 487. st. 1. toč. 3. ZTD), dužnošću vladajućeg društva da pokrije ovisnome društvu svaki godišnji gubitak nastao tijekom trajanja ugovora koji ne bi bio pokriven iz zakonskih rezervi (čl. 489. ZTD) i pravom vjerovnika na osiguranje tražbina nastalih prije objave upisa prestanka ugovora o vođenju poslova društva u sudski registar (čl. 490. st. 1. ZTD). Vanjski dioničari ovisnoga društva su zaštićeni pravilima o primjernoj naknadi najmanje u visini godišnjih iznosa koji bi se mogli isplatiti kao predvidiva prosječna dividenda za pojedinu dionicu (čl. 491. ZTD) te opcijom izlaska iz društva uz primjerenu otpremninu u dionicama vladajućeg društva ili u novcu (čl. 492. ZTD).

Drugi je zaključak da vladajuće društvo ne može davati obvezujuće upute organima ovisnoga društva kojima nije povjereno vođenje poslova ovisnoga društva. To se ponajprije odnosi na nadzorni odbor i glavnu skupštinu. ${ }^{30}$ Što se tiče upravnog odbora, kojemu su povjerene i upravljačke i nadzorne funkcije (čl. 272.h st. 1. ZTD), vladajuće društvo bi mu moglo davati obvezujuće upute samo u pogledu njegovih upravljačkih funkcija (vođenja društva, nasuprot vođenju poslova društva, za što su ovlašteni izvršni direktori). To se može posredno zaključiti iz čl. 493. st. 3. ZTD prema kojemu ako se upravi, odnosno izvršnim direktorima ovisnoga društva daju upute da obavi neki posao za koji je potrebna suglasnost nadzornog, odnosno upravnog odbora ovisnoga društva, pa taj odbor ne da suglasnost u primjerenome roku, uprava, odnosno izvršni direktori to moraju priopćiti vladajućemu društvu, a ako vladajuće društvo ponovi uputu, suglasnost nadzornog, odnosno upravnog odbora više nije potrebna. ${ }^{31}$ Pritom treba imati na umu da su, za razliku od uprave i nadzornog odbora, izvršni direktori dužni slijediti upute upravnog odbora. ${ }^{32}$ Drugim riječima, iz okolnosti da vladajuće društvo ponavljanjem upute izvršnim direktorima može „nadvladati“ upravni odbor može se zaključiti da je ono podređeno vladajućem društvu u pogledu upravljanja društvom.

Treći je zaključak da vladajuće društvo nije dužno davati obvezujuće upute upravi ovisnoga društva, odnosno voditi poslove ovisnoga društva. ${ }^{33}$ To je vidljivo

30 Barbić, J., Opći dio, op. cit. u bilj. 3, str. 713; Altmeppen, H., op. cit. u bilj. 5, § 308, para. 86.

31 Ako vladajuće društvo ima nadzorni, odnosno upravni odbor, uputa se može ponoviti samo uz odobrenje toga odbora (čl. 493. st. 3. ZTD).

32 Barbić, J., Pravo društava, Knjiga druga, Društva kapitala, Svezak I., Dioničko društvo, Zagreb, Organizator 2013, str. 1106.

33 Emmerich, V., op. cit. u bilj. 3, § 308, para. 34; Altmeppen, H., op. cit. u bilj. 5, § 309, para. 50 i dalje; Krieger, G. u: Hoffmann-Becking, M. (ur.), Münchener Handbuch des Gesellschaftsrechts, Band IV, München, C. H. Beck, 2015, § 71, para. 160. 
već iz zakonskog izričaja koji govori samo da je vladajuće društvo „ovlašteno“ davati upute. ${ }^{34}$ Vladajuće društvo nije dužno voditi poslove ovisnoga društva, među ostalim, i jer uprava ovisnoga društva nastavlja postojati i voditi poslove ovisnoga društva. ${ }^{35}$ U odsustvu uputa vladajućeg društva, uprava ovisnoga društva mora voditi poslove prema općim pravilima, u interesu ovisnoga društva, pozornošću urednog i savjesnoga gospodarstvenika (čl. 252. st. 1. ZTD). ${ }^{36}$ Drugim riječima, ugovor o vođenju poslova društva daje vladajućem društvu samo mogućnost, ne i obvezu upravljanja ovisnim društvom.

Od toga treba razlikovati dužnost vođenja poslova ovisnoga društva koju uprava vladajućeg društva može imati prema vladajućem društvu. ${ }^{37}$ Ako, naime, upravljanje ovisnim društvom i općenito koncernom, ulazi u predmet poslovanja vladajućeg društva, njegova uprava ovlaštena je i dužna upravljati čitavim koncernom. Ta dužnost ne proizlazi iz ugovora o vođenju poslova društva, nego iz općih pravila prava društava o dužnostima i odgovornosti uprave prema vlastitom društvu (čl. 252. ZTD).

Četvrti je zaključak da, čak i kada daje obvezujuće upute, vladajuće društvo ne preuzima izravno upravljačke funkcije ovisnoga društva, nego je na upravi ovisnoga društva da ih provede. To je osobito očito u odnosu s trećim osobama prema kojima i dalje uprava ovisnoga društva zastupa društvo. ${ }^{38}$ Ako se vođenje poslova ovisnoga društva podvrgava vladajućem društvu, postavlja se pitanje zašto uopće zadržati upravu ovisnoga društva? Ne bi li bilo učinkovitije kada bi vladajuće društvo izravno vodilo poslove ovisnoga društva pa čak ga i zastupalo prema trećim osobama (naravno uz odgovarajući upis u sudski registar)? Problem je što u tom slučaju, barem iz perspektive upravljanja, ne bi bilo razlike između ugovora o vođenju poslova društva i pripajanja društava, odnosno došlo bi do potpunoga zanemarivanja odvojenih pravnih osobnosti. Vladajuće se društvo koje želi osigurati maksimalni stupanj kontrole, dakle treba poslužiti odgovarajućom statusnom promjenom s odgovarajućim pretpostavkama i pravnim učincima. S druge strane, odvojena pravna osobnost povezanih društava uvijek podrazumijeva i određeni stupanj upravljačke samostalnosti.

Odvojena pravna osobnost kao i njezina upravljačka samostalnost bi, međutim, ostale puki naziv i apstrakcija kada bi uprava ovisnoga društva morala slijediti baš svaku uputu vladajućeg društva. Da postoje određene iznimke vidljivo je već iz čl. 493. st. 1. ZTD koji kaže da vladajuće društvo može davati upute koje su štetne za ovisno društvo samo ako služe interesima vladajućega društva ili drugih društava istoga koncerna. Svrha pravila o ugovoru o vođenju poslova društva je unaprijediti gospodarski položaj vladajućeg društva i čitavoga koncerna, a ne eventualno

34 Usp. s čl. 252. st. 1. ZTD prema kojemu članovi uprave "moraju" voditi poslove društva s pozornošću urednog i savjesnoga gospodarstvenika.

35 Barbić, J., Opći dio, op. cit. u bilj. 3, str. 715.

36 Koch, J., op. cit. u bilj. 3, § 291, para. 37. Iako bi se i u tom slučaju uprava ovisnoga društva o bitnijim odlukama trebala konzultirati s vladajućim društvom (Veil, R. u: Spindler, G.; Stilz, E. (ur.), Kommentar zum Aktienrecht, Band 2, München, C. H. Beck, 2015., § 308, para. 23).

37 Emmerich, V., op. cit. u bilj. 3, § 308, para. 35; Krieger, G., op. cit. u bilj. 33, § 71, para. 160.

38 VSRH Revt 60/04-2 od 6.10.2004. 
privilegirati određenu (fizičku) osobu u njezinu nepoduzetničkom svojstvu. ${ }^{39} \mathrm{Zbog}$ toga se, kao što je već rečeno, pravila o povezanim društvima primjenjuju na „poduzeća“. Ovisno bi društvo teoretski moglo zlorabiti to pravilo, tako da upute koje su za njega štetne odbije slijediti pod izlikom da su štetne i za vladajuće društvo i ostala društva koncerna. Da bi se to izbjeglo, zakon predviđa da uprava ovisnoga društva može odbiti postupiti po uputama samo kada je očito da one ne služe interesima vladajućeg društva ili ostalih društva koncerna (čl. 493. st. 2. ZTD). Kad god nedostaje očitost, uprava ovisnoga društva nije ovlaštena ignorirati upute vladajućeg društva, iako su one možda stvarno protupravne. ${ }^{40}$

Osim toga, uprava ovisnoga društva mora odbiti slijediti upute koje su protivne zakonu, statutu društva ili odredbama ugovora o vođenju poslova društva. ${ }^{41}$ Tako, primjerice, vladajuće društvo ne bi moglo uputiti upravu ovisnog društva da ne izdvaja predviđeni iznos u zakonske rezerve (čl. 487. st. 1. toč. 3. ZTD), da ne zahtijeva pokriće gubitaka (čl. 489. ZTD) da oslobodi članove društva obveze uplate uloga (čl. 212. ZTD) ili da stječe vlastite dionice protivno zakonskim pravilima (čl. 233. ZTD). ${ }^{42}$ Bitno je, međutim, primijetiti da u odnosima između vladajućeg i ovisnog društva vladajuće društvo ne mora poštovati načelo očuvanja kapitala. Prema čl. 479. st. 3. ZTD plaćanja društva na temelju ugovora o vođenju poslova društva ne smatraju se suprotnima odredbama čl. 217. ZTD (zabrana povrata plaćenog), čl. 220. ZTD (upotreba dobiti) i čl. 223. ZTD (podjela dobiti). Da isto vrijedi i za društvo s ograničenom odgovornošću proizlazi iz čl. 407. st. 1., prema kojemu se na činidbe vladajućem društvu iz ugovora o vođenju poslova društva ne primjenjuje pravilo o nedopuštenim primanjima. To znači da bi ovisno društvo moralo staviti svoju imovinu na raspolaganje vladajućem društvu da ju ono koristi za potrebe koncerna. Uprava ovisnog društva, primjerice, ne bi smjela odbiti prenijeti neki imovinski predmet drugom društvu koncerna ispod tržišne cijene. ${ }^{43}$ Ipak, vladajuće društvo ne bi moglo uputiti ovisno društvo da mu prenese svoju dobit ako nije usporedno sklopljen ugovor o prijenosu dobiti ili ugovor o djelomičnom prijenosu dobiti (čl. 479. st. 1., čl. 480. st. 1. toč. 2. ZTD). Odlučivanje o upotrebi dobiti je, naime, u nadležnosti glavne skupštine, a ne uprave društva. ${ }^{44}$

Često se ističe da nisu dopuštene upute koje bi za vrijeme trajanja ugovora ili nakon njegovog prestanka ugrozile opstanak ovisnoga društva. ${ }^{45}$ Opstanak društva bi, međutim, u oba slučaja morao biti dostatno zaštićen obvezom vladajućeg društva da pokriva gubitke ovisnoga društva (čl. 489. ZTD) ${ }^{46}$ Moguće je da već u trenutku

39 Altmeppen, H., op. cit. u bilj. 5, § 308, para. 102-103.

40 Veil, R., op. cit. u bilj. 36, § 308, para. 35.

41 Barbić, J., Opći dio, op. cit. u bilj. 3, str. 713; Koch, J., op. cit. u bilj. 3, § 308, para. 13; Veil, R., op. cit. u bilj. 36, § 308, para. 28-30.

42 Altmeppen, H., op. cit. u bilj. 5, § 308, para. 95.

43 Barbić, J., Opći dio, op. cit. u bilj. 3, str. 713; Altmeppen, H., op. cit. u bilj. 5, § 308, para. 96-98.

44 Emmerich, V., op. cit. u bilj. 3, § 308, para. 43; Veil, R., op. cit. u bilj. 36, § 308, para. 21.

45 Barbić, J., Opći dio, op. cit. u bilj. 3, str. 713; Koch, J., op. cit. u bilj. 3, § 308, para. 19; Altmeppen, H., op. cit. u bilj. 5, § 308, para. 120.

46 Altmeppen, H., op. cit. u bilj. 5, § 308, para. 122-133; Veil, R., op. cit. u bilj. 36, § 308, para. 31. Drukčije je jedino kada bi štetne upute dovele do nastanka stečajnog razloga prije nego što bi vladajuće društvo krajem poslovne godine stiglo pokriti gubitke. U tom bi slučaju vladajuće 
davanja štetne upute vladajuće društvo nije u stanju pokriti gubitak. U tom bi slučaju uprava ovisnoga društva trebala odbiti štetnu uputu čak i kada takva uputa ne bi ugrozila opstanak društva ${ }^{47}$ Pokrivanje gubitaka ovisnoga društva, naime, nužna je protuteža davanju uputa koje su štetne za ovisno društvo. ${ }^{48}$

Pod učinkovitim upravljanjem ugovornim koncernom podrazumijeva se, dakle, upravljanje koje je učinkovito iz perspektive vladajućeg društva, odnosno koncerna kao cjeline kojim upravlja vladajuće društvo. Okolnost da određena uputa nije učinkovita iz perspektive ovisnoga društvo ne ovlašćuje to društvo da ju odbije provesti. Ipak, čak i takvo objedinjavanje upravljanja nailazi na nužne granice koje proizlaze iz odvojene pravne osobnosti društava koncerna. Ovisno društvo tako zadržava svoju upravu čija je funkcija kontrola zakonitosti uputa vladajućeg društva. Najvažniji element zakonitosti upravo je ostvarenje svrhe ugovora o vođenju poslova društva. Zbog toga bi uprava ovisnoga društva mogla odbiti uputu koja bi dovela do gubitaka ovisnoga društva koje vladajuće društvo ne bi bilo u stanju pokriti ili uputu koja ne služi interesima vladajućeg društva ili drugih društava koncerna.

Takva kontrolna funkcija uprave ovisnoga društva kogentne je naravi. U tome se smislu može kazati da su opća pravila o korporativnom upravljanju i odnosima organa društva kod ugovora o vođenju poslova društva dijelom izmijenjena zbog postojanja ugovornog koncerna, no da i dalje opstaju kogentna pravila koja postavljaju granice koliko se ta opća pravila o korporativnom upravljanju mogu izmijeniti. Zbog toga bi se vladajućem društvu mogao osigurati izravan utjecaj u ovisno društvo samo uz poštivanje općih pravila prava društava o granicama utjecaja na vođenje poslova i zastupanje društva. Primjerice, članovi uprave vladajućeg društva mogli be zastupati ovisno društvo samo ako im ovisno društvo dade prokuru ili neki drugi oblik punomoći. ${ }^{49}$ Jednako tako, uprava ovisnog društva ne bi mogla ovlastiti vladajuće društvo da izravno daje upute zaposlenicima ovisnoga društva, barem bez da je uspostavila odgovarajući sustav kontrole takvih uputa. ${ }^{50}$ Uvijek je moguće da, uz poštovanje općih pravila prava društava, iste osobe budu izabrane u upravu i ovisnog i vladajućeg društva. ${ }^{51}$

Izloženi sustav upravljanja u ugovornom koncernu nužno se odražava na pravila o odgovornosti za štetu koja nastane ovisnome društvu. Tako pravilo o odgovornosti zakonskih zastupnika vladajućeg društva ako pri davanju upute ovisnome društvu ne primijene pozornost urednog i savjesnog voditelja poslova (čl. 494. st. 1. i 2. ZTD) treba shvatiti na način da su zakonski zastupnici odgovorni samo ako ne primijene

društvo bilo dužno spriječiti nastanak stečajnog razloga odgovarajućim ranijim pokrivanjem gubitaka (Altmeppen, H., op. cit. u bilj. 5, § 308, para. 125).

47 Altmeppen, H., op. cit. u bilj. 5, § 302, para. 40.; Heidinger, A. u: Michalski, L.; Heidinger, A.; Leible, S.; Schmidt, J. (ur.), Kommentar zum GmbHG, Band 1, München, C. H. Beck, 2017., § 30, para. 214.

48 V. Bilić, A., Uzlazna sredstva osiguranja (Upstream guarantees), Zbornik 56. susreta Pravnika u gospodarstvu, Opatija 2018, Zagreb, 2018., str. 206.

49 VSRH Revt 60/04-2 od 6.10.2004.; Altmeppen, H., op. cit. u bilj. 5, § 308, para. 21.

50 Emmerich, V., op. cit. u bilj. 3, § 308, para. 19-20.

51 Emmerich, V., op. cit. u bilj. 3, § 308, para. 29. 
odgovarajuću pozornost u odnosu na koncern kao cjelinu..$^{52}$ Jednako tako, pravilo da članovi organa ovisnoga društva odgovaraju solidarno za nastalu štetu ako svojim djelovanjem povrijede svoje obveze (čl. 495. st. 1. ZTD) odnosi se ponajprije na situaciju kada članovi uprave ovisnoga društva povrijede svoje dužnosti kontrole uputa vladajućeg društva. ${ }^{53}$

Usprkos mnogim očitim prednostima koje nosi, čini se, ipak da ugovor o vođenju poslova društva nije zaživio u praksi. Dostupna sudska praksa pokazuje da se naziv „,ugovor o vođenju poslova“ najčešće koristi u netehničkom smislu, kao naziv za svojevrsni menadžerski ugovor između društva i njegovih direktora. ${ }^{54}$ Sudovi ispravno koriste naziv „,ugovor o vođenju poslova društva“ najčešće pri utvrđivanju da takav ugovor nije postojao u konkretnom slučaju. ${ }^{55}$ Iako se o razlozima relativne nepopularnosti ugovora o vođenju poslova društva može samo nagađati, ne bi začudilo da je to posljedica okolnosti što vladajuća društva često smatraju da ih već i faktični koncern ovlašćuje voditi poslove društva zanemarujući interese ovisnoga društva. $\mathrm{O}$ razlikama u tom pogledu između ugovornog i faktičnog koncerna bit će više govora u nastavku rada.

\section{UČINKOVITO UPRAVLJANJE KONCERNOM PRIKLJUČENIH DRUŠTAVA}

Kao i ugovor o vođenju poslova društva, priključenje društava kapitala stvara neoborivu presumpciju da između povezanih društava postoji jedinstveno vođenje, odnosno koncern (čl. 476. ZTD). Do priključenja društava kapitala dolazi na temelju odluke glavne skupštine priključenoga (ovisnoga) društva uz uvjet da glavno (vladajuće) društvo ima sve dionice ili poslovne udjele u ovisnom društvu (čl. 503. st. 1. ZTD). Do priključenja može doći i ako glavno društvo ima barem $95 \%$ dionica, odnosno poslovnih udjela u ovisnome društvu, s time da tada upisom priključenja $u$ sudski registar priključenoga društva sve dionice, odnosno poslovni udjeli u ovisnome društvu prelaze na glavno društvo (čl. 504.a st. 1. ZTD). ${ }^{56}$ Dotadašnji manjinski članovi priključenoga društva imaju pravo na primjerenu otpremninu, u prvom redu u dionicama, odnosno poslovnim udjelima glavnoga društva (čl. 504.a st. 2. ZTD). ${ }^{57}$

Za učinkovito upravljanje u koncernu priključenjem ključna je odredba prema kojoj je glavno društvo ovlašteno glede vođenje poslova davati upute upravi, odnosno izvršnim direktorima priključenoga društva (čl. 507. st. 1. ZTD). Ona podsjeća na

52 Altmeppen, H., op. cit. u bilj. 5, § 309, para. 71; Emmerich, V., op. cit. u bilj. 3, § 309, para. 33.

53 Emmerich, V., op. cit. u bilj. 3, § 310, para. 11.

54 VSRH Revt 328/12-2 od 14.1.2014.; VSRH Gr1 374/2010-2 od 16.12.2010.; VSRH VSRH Gzp 74/2007-5 od 24.4.2007.; VTS Pž 4506/04-3 od 13.6.2007.; Pž 7763/2015-5 od 13.9.2017.

55 VSRH Revt 60/04-2 od 6.10.2004.; VSRH VSRH I Kž 510/2005-7 od 20.3.2017.; VTS Pž 7252/07-3 od 15.1.2008. Samo u jednoj pronađenoj presudi (ŽS Split Gžrs 99/2013-2 od 25.2.2016.) drugostupanjski sud se pozvao na zaključke prvostupanjskog suda da je između društva s ograničenom odgovornošću i dioničkog društva postojao ugovor o vođenju poslova društva u smislu čl. 479. ZTD-a.

56 Riječ je o svojevrsnom squeeze out-u, usp. s. čl. 300.f ZTD.

57 Više o priključenju v. Barbić, J., Opći dio, op. cit. u bilj. 3, str. 733 i dalje. 
odgovarajuće pravilo u ugovornom koncernu (čl. 493. st. 1. ZTD). To znači da se i na koncern priključenjem načelno mogu primijeniti četiri već izložena zaključka - glavno društvo može vršiti odlučujući utjecaj na priključeno društvo putem obvezujućih uputa; glavno društvo može davati upute samo poslovodnim organima priključenoga društva, dakle upravi ili izvršnim direktorima; glavno društvo nije dužno davati obvezujuće upute priključenom društvu i naposljetku, čak i kada daje obvezujuće upute, glavno društvo ne upravlja izravno priključenim društvom, nego provođenje uputa ostaje u nadležnosti uprave priključenog društva. Zbog toga, među ostalim, ne začuđuje da odredbe o vođenju poslova i odgovornosti u koncernu priključenjem upućuju na odgovarajuću primjenu određenih odredaba o vođenju poslova u ugovornom koncernu (čl. 507. st. 1. ZTD).

Priključenje društava kapitala ipak je intenzivniji oblik povezivanja od ugovora o vođenju poslova. To se u prvom redu očituje u okolnosti da je glavno društvo jedini dioničar, odnosno član priključenoga društva. Drugim riječima, uz davanje odgovarajuće otpremnine, prestaju postojati manjinski, vanjski dioničari priključenoga društva o čijim bi interesima trebalo voditi računa. Od negativnih posljedica priključenja je, dakle, potrebno zaštititi isključivo treće osobe, odnosno vjerovnike priključenoga društva. Zbog intenzivnijeg oblika povezivanja ne čudi da je i zaštita trećih osoba intenzivnija. Od upisa priključenja glavno društvo odgovara vjerovnicima priključenoga društva kao solidarni dužnik za sve obveze toga društva, neovisno o tomu jesu li nastale prije ili nakon priključenja (čl. 506. st. 1. ZTD).

Budući da je priključenje najintenzivniji oblik povezivanja dvaju društava ne čudi da glavno društvo ima šire ovlasti davanja obvezujućih uputa od vladajućeg društva u ugovornom koncernu. Tako odredbe o vođenju poslova priključenog društva ne sadrže i ne upućuju na pravilo ugovornog koncerna prema kojemu vladajuće društvo može davati upute koje su štetne za ovisno društvo samo ako služe interesima vladajućega društva ili društva koja su s njime i s ovisnim društvom povezana u koncern (čl. 493. st. 1. ZTD). Drugim riječima, uprava priključenog društva bila bi dužna slijediti čak $i$ one upute glavnog društva koje nisu u interesu niti jednoga od društava koncerna. ${ }^{58}$ Pritom ništa ne mijenja na stvari što bi davanjem takvih uputa uprava glavnog društva povrijedila svoje dužnosti prema glavnom društvu. ${ }^{59}$ Čl. 507. st. 1. ZTD, doduše, poziva na odgovarajuću primjenu čl. 493. st. 2. ZTD, što bi se moglo shvatiti na način da uprava priključenog društva može odbiti upute glavnog društva ako je očito da one ne služe interesima glavnog društva ili drugih društava koncerna. Ipak, ako se uzme u obzir da je zakonodavac svjesno propustio uputiti na čl. 493. st. 1. ZTD, kao primarno pravilo o nužnosti interesa vladajućeg društva i drugih društava koncerna, upućivanje na čl. 493. st. 2. ZTD trebalo bi ograničiti na prvu rečenicu toga stavka prema kojoj uprava, odnosno izvršni direktori ovisnoga društva moraju slijediti upute vladajućeg društva. ${ }^{60}$

58 Barbić, J., Opći dio, op. cit. u bilj. 3, str. 745.

59 Grunewald, B. u: Goette, W.; Habersack, M. (ur.), Münchener Kommentar zum Aktienrecht, Band 5, München, C. H. Beck/Franz Vahlen, 2015., § 323, para. 2; Singhof, B. u: Spindler, G.; Stilz, E. (ur.), Kommentar zum Aktienrecht, Band 2, München, C. H. Beck, 2015., § 323, para. 6.

60 To je izričito navedeno u odredbama njemačkoga prava koje su poslužile kao uzor za čl. 507. i 
Nadalje, glavno društvo je ovlašteno upravi priključenog društva davati upute koje bi ugrozile opstanak priključenog društva. ${ }^{61}$ Kao što je već rečeno, priključeno društvo nema vanjske dioničare koje bi trebalo zaštititi, a njegovi vjerovnici dostatno su zaštićeni pravilom o solidarnoj odgovornosti vladajućeg društva.

Glavno društvo ipak ne bi bilo ovlašteno upravi priključenog društva davati upute koje su protivne zakonu ili statutu, a uprava priključenog društva bila bi ovlaštena odbiti takve upute. ${ }^{62}$ Ipak, slično kao i kod ugovora o vođenju poslova, to se ne odnosi na načelo očuvanja kapitala ovisnoga društva. Prema čl. 507. st. 2. ZTD, činidbe koje priključeno društvo ispunjava glavnom društvu nisu u suprotnosti s odredbama čl. 217. ZTD (zabrana povrata plaćenog), čl. 220. ZTD (upotreba dobiti) i čl. 223. ZTD (podjela dobiti). Isto bi, analogijom, trebalo primijeniti i na odredbe očuvanja kapitala u društvu s ograničenom odgovornošću (čl. 407. ZTD). Ne postoji, naime, razlog zašto bi, u kontekstu priključenja društava, načelo očuvanja kapitala društva s ograničenom odgovornošću bilo znatno strože nego za dioničko društvo.

Učinkovito upravljanje u koncernu priključenih društava slično je, dakle, učinkovitom upravljanju u ugovornom koncernu, odnosno učinkovitost upravljanja ocjenjuje se u prvom redu iz perspektive glavnog društva. Glavno je društvo toliko dominantno u odnosu na priključeno društvo da bi mu moglo nametnuti uputu koja ne bi koristila ni jednome od društava istoga koncerna. Kao rezidua posebne pravne osobnosti priključenog društva upravi priključenog društva ostaje još samo ovlast odbiti upute koje su protivne zakonu ili statutu priključenog društva. Zbog takve radikalne integracije priključenih društava smatra se da se institut priključenja nalazi na pola puta između ugovornog koncerna i statusne promjene pripajanja. ${ }^{63}$

Izgleda da je institut priključenja društava u praksi još rjeđe korišten od ugovora o vođenju poslova društva. U svakom slučaju, indikativno je da se u dostupnim sudskim presudama uopće ne spominje. Mogući razlog tomu je što je priključenje toliko blizu statusnoj promjeni pripajanja da se društva kapitala radije odlučuju na taj, manje „egzotičan“ institut. Drugim riječima, ako glavno društvo već mora, uz odgovarajuću otpremninu, preuzeti sve dionice priključenoga društva te odgovarati za obveze priključenoga društva, nema razloga zašto ne bi pripojilo priključeno društvo i time steklo izravnu ovlast vođenje njegovih poslova.

\section{UČINKOVITO UPRAVLJANJE U FAKTIČNOM KONCERNU}

Faktični koncern svaki je oblik jedinstvenog upravljanja vladajućim i ovisnim društvom koji se ne temelji na ugovoru o vođenju poslova društva ili priključivanju društava. Zakon predviđa oborivu presumpciju da ovisno i vladajuće društvo čine

čl. 493. st. 2. ZTD (§ 323 (1) i § 308 (1) AktG).

61 Barbić, J., Opći dio, op. cit. u bilj. 3, str. 745.; Grunewald, B., op. cit. u bilj. 59, § 323, para. 3.; Habersack, M. u: Emmerich, V.; Habersack, M.; Schürnbrand, J. (ur.), Aktien- und GmbHKonzernrecht, München, C. H. Beck, 2016., § 323, para. 2. Drukčije Singhof, B., op. cit. u bilj. $59, \S 323$, para. 2 .

62 Grunewald, B., op. cit. u bilj. 59, § 323, para. 5.; Habersack, M., op. cit. u bilj. 61, § 323, para. 2; Singhof, B., op. cit. u bilj. 59, § 323, para. 2.

63 Barbić, J., Opći dio, op. cit. u bilj. 3, str. 734. 
koncern (čl. 476. st. 1. ZTD). Takav se koncern naziva faktičnim jer ne postoji posebna pravna osnova koja bi ovlašćivala vladajuće društvo na jedinstveno upravljanje, nego vladajuće društvo koristi moć koja proizlazi iz općih pravila korporativnoga statusnog prava, u prvom redu iz većine udjela u temeljnom kapitalu ili iz većinskoga prava glasa (čl. 474. ZTD). To utječe i na pravila o učinkovitom upravljanju u faktičnom koncernu. Ako nadređenost jednog društva drugome proizlazi iz općih statusnih pravila, onda granice njegovog utjecaja ne smiju znatno odudarati od općih granica utjecaja člana na vođenje poslova društva. U suprotnom bi se, naime, vladajuća društva u sastavu koncerna našla u neopravdano privilegiranom položaju u odnosu na većinske članove koji se ne nalaze u koncernu. ${ }^{64}$

Izgleda da je faktični koncern u hrvatskoj poslovnoj praksi rasprostranjeniji od ugovornoga koncerna i koncerna priključenih društava, najvjerojatnije i zbog toga što nastaje „automatski“, stjecanjem većine udjela ili prava glasa. Njegovu veću učestalost sugerira i sudska praksa. ${ }^{65}$

Osnovno pravilo je sadržano u čl. 496. st. 1, ZTD prema kojemu ako nije sklopljen ugovor o vođenju poslova društva, vladajuće društvo ne smije koristiti svoj utjecaj da ovisno društvo uputi na to da poduzme štetne pravne poslove ili da poduzme ili propusti radnje na svoju štetu, osim ako se vladajuće društvo obveže da će ovisnome društvu nadoknaditi štetu koja bi mu time nastala. Na prvi je pogled vidljivo da je to pravilo uobličeno dijametralno suprotno od pravila o upravljanju ugovornim koncernom i koncernom priključenjem. Dok pravila o upravljanju ugovornim koncernom i koncernom priključenjem ovlašćuju vladajuće društvo na davanje uputa, pravila o upravljanju faktičnim koncernom usmjerena su na zabranu uputa. Primarna svrha takvog pravila je zaštititi manjinske članove i vjerovnike ovisnoga društva. ${ }^{66}$

Nije sporno da između faktičnog i ugovornoga koncerna (i koncerna priključenjem) postoje i mnoge sličnosti. Za početak, ovisno društvo uvijek zadržava svoju vlastitu upravu, odnosno izvršne direktore (v. čl. 497., 502. ZTD). Uprava ovisnoga društva dužna je voditi poslove ovisnoga društva prema općim pravilima, pozornošću urednog i savjesnoga gospodarstvenika (čl. 252. ZTD). ${ }^{67} \mathrm{Ne}$ može se, dakle, dogoditi da vladajuće društvo izravno vodi poslove ovisnoga društva.

Nadalje, vladajuće društvo nema obvezu prema ovisnome društvu voditi njegove poslove ${ }^{68}$ Kao što je već objašnjeno, vladajuće društvo nema takvu obvezu ni u ugovornom koncernu kao ni u koncernu priključenjem. Ona tim više ne bi trebala postojati u faktičnom koncernu u kojem vladajuće društvo ima znatno manji utjecaj na ovisno društvo. Na to ne utječe okolnost da je, u okviru zakonskih granica, uprava

64 Osobito u odnosu na većinske članove koji su fizičke osobe i ne obavljaju gospodarsku djelatnost izvan sudjelovanja u konkretnom društvu. V. i Bilić, A.; Petrović, S., op. cit. u bilj. 11, str. 735 .

65 VSRH Revt 159/11-2 od 24.1.2012. i VTS Pž-1760/02 od 15.4.2003. (sentenca na IUSinfo); VTS Pž-1934/06-3 od 22.4.2009.

66 Barbić, J., Opći dio, op. cit. u bilj. 3, str. 656, gdje kaže da je riječ o zaštitnom pravilu; Habersack, M., op. cit. u bilj. 61, § 311, para. 1.; Altmeppen, H., op. cit. u bilj. 5, § 311, para. 3 i dalje.

67 Müller, H-F. u Spindler, G.; Stilz, E. (ur.), Kommentar zum Aktienrecht, Band 2, München, C. H. Beck, 2015., § 311, para. 62.

68 Habersack, M., op. cit. u bilj. 61, § 311, para. 10. 
vladajućeg društva prema vladajućem društvu dužna zastupati njegove interese u ovisnim društvima. Riječ je, naime, o općim dužnostima uprave prema njezinu vlastitom društvu koje ne predstavljaju osobitost faktičnoga koncerna. ${ }^{69}$

Između faktičnog i ugovornog koncerna postoje dvije temeljne razlike. Prva je da vladajuće društvo ne smije uputiti ovisno društvo na poduzimanje radnji koje bi bile štetne po ovisno društvo. Za razliku od ugovornoga koncerna nije dostatno da su upute korisne za vladajuće društvo ili neko drugo društvo istoga koncerna. Nužno je, dakle, utvrditi što se smatra radnjom štetnom po ovisno društvo. ${ }^{70}$ Štetnost se shvaća kao svako smanjenje ili ugrožavanje imovine ovisnoga društva. ${ }^{71}$ To se utvrđuje usporedbom s hipotetskim ponašanjem fiktivnog, neovisnog, uredno vođenog društva, koje je, uz iznimku ovisnosti, istovjetno ovisnome društvu. ${ }^{72}$ Ako bi, dakle, uredan i savjestan voditelj poslova nekoga nezavisnog društva ušao u određeni pravni posao ili bi poduzeo ili propustio određenu radnju ne može se govoriti o radnji štetnoj po ovisno društvo (čl. 501. st. 3. ZTD). ${ }^{73}$ Štetnost radnje ocjenjuje se ex ante, u trenutku njezinog poduzimanja. ${ }^{74}$

$\mathrm{U}$ tom pogledu, pravila o faktičnom koncernu u potpunosti se podudaraju s općim pravilom prava društava prema kojemu članovi društva ne smiju društvu nanositi štetu. To proizlazi već iz temeljne članske obveze na lojalno postupanje koja, među ostalim, podrazumijeva zabranu nanošenja štete društvu i ostalim članovima društva. ${ }^{75} \mathrm{U}$ širem, građanskopravnom kontekstu, to je odraz opće zabrane prouzročenja štete (čl. 8. Zakona o obveznim odnosima ${ }^{76}$ ), koja tim više vrijedi u društvima kao privatnopravnim zajednicama nastalim na temelju pravnog posla. Članska bi dužnost lojalnosti, doduše, izgubila na važnosti u društvu s ograničenom odgovornošću $\mathrm{s}$ jednim članom..$^{77} \mathrm{U}$ takvom bi društvu jedini član mogao davati upute koje su štetne po društvo dok god se njima ne vrijeđaju propisi koji služe zaštiti vjerovnika.

Okolnost da vladajuće društvo ne smije uputiti ovisno društvo na poduzimanje radnji koje bi bile štetne po ovisno društvo ne znači automatski da uprava ovisnoga društva može odbiti takvu štetnu uputu. Budući da pravo povezanih društava o tomu ništa ne govori, odgovor treba pronaći u općim pravilima za svaki pojedini oblik ovisnoga društva. Tako u dualistički ustrojenom dioničkom društvu uprava vodi poslove društva na vlastitu odgovornost (čl. 240. st. 1. ZTD) pažnjom urednog i

69 Habersack, M., op. cit. u bilj. 61, § 311, para. 11.

70 Detaljnije v. Bilić, A.; Petrović, S., op. cit. u bilj. 11, str. 735-736.

71 Barbić, J., Opći dio, op. cit. u bilj. 3, str. 658.

72 Barbić, J., Opći dio, op. cit. u bilj. 3, str. 658, 671; Habersack, M., op. cit. u bilj. 61, § 311, para. 41, 53.

73 Habersack, M., op. cit. u bilj. 61, § 311, para. 40.

74 Barbić, J., Vođenje poslova i upravljanje, op. cit. u bilj. 6, str. 1581; Müller, H-F., op. cit. u bilj. 67, § 311, para. 29; Habersack, M., op. cit. u bilj. 61, § 311, para. 44.

75 Barbić, J., Pravo društava, Knjiga treća, Društva osoba, Zagreb, Organizator 2002., str. 75, 357; Barbić, J., Dioničko društvo, op. cit. u bilj. 32, str. 540; Barbić, J., Pravo društava, Knjiga druga, Društva kapitala, Svezak II., Društvo s ograničenom odgovornošću, Zagreb, Organizator, 2013., str. 234.

76 NN 35/2005, 41/2008, 125/2011, 78/2015.

77 Merkt, H. u: Fleischer, H.; Goette, W. (ur.), Münchener Kommentar zum GmbHG, Band 1, München, C. H. Beck, 2018, § 13, para. 105-106. 
savjesnoga gospodarstvenika (čl. 252. ZTD). To znači da bi uprava bila dužna odbiti svaku uputu nadzornog odbora ili glavne skupštine koja bi umanjivala ili ugrožavala imovinu društva. Uprava bi bila dužna slijediti upute glavne skupštine samo u pogledu relativno malog broja odluka koje su zakonom stavljene u nadležnost glavne skupštine ili ako je uprava samoinicijativno zatražila da glavna skupština odluči o nekim pitanjima vođenja poslova. ${ }^{78}$ Uprava, međutim, ne bi smjela provesti ništetne odluke glavne skupštine. Ako je odluka glavne skupštine pobojna, a njezina provedba bi društvu prouzročila štetu, uprava bi trebala odgoditi njezino provođenje i pokušati ju pobiti (čl. 362. st. 1. toč. 4-5. ZTD). ${ }^{79}$

Ista pravila načelno vrijede i za monistički ustroj ovisnoga dioničkog društva. Iako su tamo izvršni direktori hijerarhijski podređeni upravnom odboru i dužni su slijediti njegove upute, ${ }^{80}$ upravni odbor morao bi voditi društvo u najboljem interesu društva (čl. 272.k ZTD), neovisno o glavnoj skupštini, a onda i o većinskom dioničaru ${ }^{81} \mathrm{U}$ monističkom ustroju ipak su veća vjerojatnost da će vladajuće društvo, makar protuzakonito, nametnuti svoju upute ovisnome društvu zbog toga što, za razliku od članova uprave, glavna skupština izravno bira članove upravnog odbora (čl. 272.c ZTD) i zbog toga što nije potreban važan razlog za njihov opoziv (čl. 272.e ZTD).

Izloženo se, međutim, ne može primijeniti na ovisno društvo s ograničenom odgovornošću. U društvu s ograničenom odgovornošću uprava vodi poslove društva u skladu s društvenim ugovorom, odlukama članova društva i obveznim uputama skupštine i nadzornog odbora, ako ga društvo ima (čl. 422. st. 2. ZTD). Iz toga se može zaključiti da je uprava dužna slijediti čak i one upute koje su štetne za društvo. ${ }^{82}$ Ne bi se, naime, moglo govoriti o podvrgavanju uprave skupštini i nadzornom odboru kada bi uprava bila slobodna samostalno prosuđivati koje su upute štetne za društvo i odbijati takve upute. To ne znači da uprava ne bi mogla, u okviru svojih ovlasti vođenja poslova, upozoriti da je neka uputa štetna. Jednako tako, to, ne znači da je članovima društva dopušteno davati upute koje bi bile štetne za društvo, jer bi, kao što je već rečeno, to bilo protivno obvezi lojalnog postupanja. ${ }^{83}$ Uprava, međutim, ne bi mogla odbiti takve nedopuštene štetne upute nego bi eventualno mogla tražiti naknadu štete pod pretpostavkama čl. $273 .{ }^{84} \mathrm{i}$ čl. 501. ZTD ${ }^{85}$

Uprava društva s ograničenom odgovornošću, ipak, može, pa čak i mora, odbiti slijediti upute članova, skupštine ili nadzornog odbora koje bi zadirale u neotuđivu nadležnost uprave brinuti se o zakonitosti postupanja društva (compliance). ${ }^{86}$ Takve

78 Barbić, J., Dioničko društvo, op. cit. u bilj. 32, str. 779.

79 Spindler, G. u: Goette, W.; Habersack, M. (ur.), Münchener Kommentar zum GmbHG, Band 2, München, C. H. Beck, 2014., § 93, para. 237.

80 Barbić, J., Dioničko društvo, op. cit. u bilj. 32, str. 1054-1055.

81 O razdvojenosti funkcija upravnog odbora i glavne skupštine v. Barbić, J., Dioničko društvo, op. cit. u bilj. 32, str. 1055-1056.

82 Stephan, K-D.; Tieves, J. u: Fleischer, H.; Goette, W. (ur.), Münchener Kommentar zum GmbHG, Band 2, München, C. H. Beck, 2016, § 37, para. 120.

83 Barbić, J., Društvo s ograničenom odgovornošću, op. cit. u bilj. 75, str. 235-236.

84 Na koji upućuje čl. 430. ZTD.

85 Merkt, H., op. cit. u bilj. 77, para. 210.

86 Barbić, J., Društvo s ograničenom odgovornošću, op. cit. u bilj. 75, str. 381. Stephan, K-D.; 
će upute redovito biti ništetne jer se njima vrijeđaju propisi kojima se isključivo ili pretežno štite interesi vjerovnika društva ili javni interesi (čl. 448., čl. 355. st. 1. toč. 3. ZTD). Uostalom, kao što je već objašnjeno, čak i u ugovornom koncernu, kao i koncernu priključenjem uprava ovisnoga društva morala bi odbiti nezakonite upute vladajućeg društva. Međutim, za razliku od ugovornoga koncerna i koncerna priključenjem, u društvu s ograničenom odgovornošću (pa i onome koje se nalazi u sklopu faktičnog koncerna) vrijedi temeljno načelo očuvanja kapitala društva (čl. 407. st. 1. ZTD). Drugim riječima, uprava ne bi smjela slijediti uputu koja bi dovela do nedopuštenih isplata članovima društva (čl. 407. st. 3. i 7. ZTD). ${ }^{87} \mathrm{~S}$ druge strane, uprava društva načelno je dužna slijediti upute koje nisu ništetne nego samo pobojne, ${ }^{88}$ ali bi morala pričekati s njihovim provođenjem ako je izgledno da će biti pobijane. ${ }^{89}$

Može se zaključiti da koncernska zabrana vladajućem društvu da daje štetne upute ovisnom društvu (čl. 496. ZTD), kao svoje naličje, nema uvijek ovlast uprave ovisnoga društva da odbije takve upute. To će ponajprije biti slučaj u ovisnom dioničkom društvu, u kojem uprava ne mora provoditi upute drugih organa osim onih koje se nalaze u uskoj nadležnosti glavne skupštine, a koje nisu ništetne ili pobojne. $\mathrm{S}$ druge strane, u ovisnome društvu s ograničenom odgovornošću uprava mora načelno slijediti upute skupštine, čak i one koje su štetne za društvo. Uprava društva s ograničenom odgovornošću ovlaštena je i dužna odbiti samo one upute kojima bi se vrijeđala zakonitost postupanja društva, osobito načelo očuvanja kapitala. Može se, dakle, dogoditi da je uprava ovisnoga društva dužna slijediti uputu koja je iz perspektive vladajućeg društva nedopuštena. Drugim riječima, postoji diskrepancija između onoga što vladajuće društvo smije i onoga što može provesti. Ako bi takva nedopuštena uputa dovela do štete za ovisno društvo, njegova uprava mogla bi tražiti naknadu štete od vladajućeg društva i njegovih zakonskih zastupnika po posebnim koncernskim pravilima (čl. 501. ZTD) koja su za ovisno društvo povoljnija od opće odgovornosti za štetu osobe koja je s nakanom iskoristila svoj utjecaj u društvu (čl. 273. st. 1. ZTD).

Tieves, J., op. cit. u bilj. 82, § 37, para. 25, 118.

87 Stephan, K-D.; Tieves, J., op. cit. u bilj. 82, § 37, para. 120.

88 Barbić, J., Društvo s ograničenom odgovornošću, op. cit. u bilj. 75, str. 381. Iz perspektive hrvatskoga prava u najmanju ruku je upitno je li uprava društva s ograničenom odgovornošcu ovlaštena pobijati odluke skupštine. Okolnost da čl. 449. ZTD upućuje na odgovarajuću primjenu čl. 360-366. ZTD (pa tako i čl. 362. st. 1. toč. 4-5.), sugerira da je to moguće. U njemačkom pravu društava, koje je poslužilo kao uzor za uređenje hrvatskih društava kapitala, se smatra da uprava i njezini članovi nisu ovlašteni pobijati odluke članova društva i skupštine zbog toga što u društvu s ograničenom odgovornošću, za razliku od dioničkog društva, uprava ne vodi poslove na vlastitu odgovornost nego je vođenje poslova društva ultimativno podvrgnuto članovima društva (Wertenbruch, J. u: Fleischer, H.; Goette, W. (ur.), Münchener Kommentar zum GmbHG, Band 1, München, C. H. Beck, 2016, § 47 Anh., para. 191). Drugim riječima, ovlast uprave da pobija odluke skupštine teško bi se mogla pomiriti s podređenošću uprave tim istim uputama. Zbog toga bi se i za hrvatsko pravo moglo zaključiti da „odgovarajući način“ primjene odredaba o pobijanju odluka glavne skupštine u društvu s ograničenom odgovornošću isključuje ovlast uprave da pobija odluke skupštine.

89 Stephan, K-D.; Tieves, J., op. cit. u bilj. 82, § 37, para. 122; Barbić, J., Društvo s ograničenom odgovornošću, op. cit. u bilj. 75, str. 381. 
Pravilo o granicama utjecaja u faktičnom koncernu iznimno dopušta vladajućem društvu da uputi ovisno društvo na poduzimanje štetnih pravnih radnji uz uvjet da se vladajuće društvo obveže da će ovisnome društvu nadoknaditi štetu koja bi mu time nastala (čl. 496. st. 1. ZTD). Bitno je primijetiti da se ne radi o klasičnim odštetnom zahtjevu nego o posebnom zahtjevu prava društava čije ispunjenje sprječava protupravnost štetnih uputa, a time i odgovornost za štetu u smislu čl. 501. st. 1. ZTD. ${ }^{90}$

Šteta mora biti nadoknađena putem prednosti konkretno izrazivih u novcu. Ne bi dostajale apstraktne buduće prednosti zbog same činjenice postojanja koncerna. ${ }^{91}$ To je vidljivo iz pravila prema kojemu vladajuće društvo mora nadoknaditi štetu najkasnije do kraja poslovne godine u kojoj je društvu počinjena šteta ili u tom razdoblju ovisnome društvu mora dati odgovarajući zahtjev na nadoknadu štete (čl. 496 st. 2. ZTD). Nadoknada štete, odnosno zahtjev na nadoknadu štete mora se moći iskazati u istim godišnjim financijskim izvješćima u kojima se iskazuje šteta. ${ }^{92}$ Hrvatsko pravo se, dakle, drži njemačkoga predloška, a ne usvaja originalno francusku, a u Europi sve popularniju, Rozenblum doktrinu prema kojoj se uprava ovisnog društva može voditi za interesom koncerna kao cjeline, dok god može razumno očekivati određene buduće prednosti za vlastito društvo. ${ }^{93}$

Budući da ova iznimka iz čl. 496. st. 1. ZTD predstavlja iznimku koncernskoga prava u odnosu na opća pravila prava društava, ona se naziva koncernski privilegij vladajućeg društva. ${ }^{94}$ Njega je moguće opravdati samo ako ne ugrožava manjinske članove i vjerovnike ovisnoga društva ne dovodi u lošiji položaj. ${ }^{95}$ To je moguće samo ako je u trenutku davanje štetne upute bilo izgledno da vladajuće društvo može nadoknaditi štetu ovisnome društvu, odnosno da mu može dati zahtjev za nadoknadu štete, koji se u bilanci može iskazati u nominalnom iznosu. ${ }^{96}$

Druga temeljna razlika između faktičnog i ugovornoga koncerna je u tomu što pravila o faktičnom koncernu ne nameću ovisnome društvu dužnost da slijedi bilo koje upute vladajućeg društva, dakle ni one upute koje za njega nisu štetne pa čak ni one koje su za njega očito korisne. ${ }^{97}$ To proizlazi iz izričaja čl. 496. st. 1. ZTD, koji je

90 V. Bilić, A.; Petrović, S., op. cit. u bilj. 11, str. 737.

91 Altmeppen, H., op. cit. u bilj. 5, § 311, para. 306, 340; Müller, H-F., op. cit. u bilj. 67, § 311, para. 50.

92 Barbić, J., Opći dio, op. cit. u bilj. 3, str. 661-662.

93 Winner, M., Group Interest in European Company Law: an Overview, Acta Univ. Sapientiae, Legal Studies, vol. 5, 2016, br. 1, str. 88; Hansen, J. L., The Report of the Reflection Group on the Future of EU Company Law-As seen from a Nordic perspective, Nordic \& European Company Law Working Paper no. 10-15, 2011., str. 17-18 (https://papers.ssrn.com/sol3/papers. cfm?abstract_id=1869817, 31.8.2018.); Funatsu, K., Trends in European Corporate Group Law Systems and the Future of Japan's Corporate Law System, Policy Research Institute, Ministry of Finance, Japan, Public Policy Review, vol. 11, no.3, July 2015, str. 477-478. V. i 16. odjeljak European Model Company Act (EMCA).

94 Habersack, M., op. cit u bilj. 61, § 311, para. 2.

95 Altmeppen, H., op. cit. u bilj. 5, § 311, para. 305 i dalje.

96 Altmeppen, H., op. cit. u bilj. 5, § 311, para. 465, 471.

97 Altmeppen, H., op. cit. u bilj. 5, § 311, para. 464.; Habersack, M., op. cit. u bilj. 61, § 311, para. 78 , gdje kaže da uprava ovisnoga društva u najboljem slučaju može imati prema ovisnome društvu dužnost slijediti povoljnu uputu. 
oblikovan na način da vladajućem društvu zabranjuje štetne, a ne da ga ovlašćuje na davanje ne-štetnih uputa. Ni tzv. koncernski privilegij, odnosno davanje zahtjeva za nadoknadu štete, ne ovlašćuje vladajuće društvo na davanje takvih uputa. ${ }^{98}$ To znači da su za granice utjecaja vladajućeg društva davanjem ne-štetnih uputa ponovno mjerodavna opća pravila za pojedini oblik ovisnoga društva. Drugim riječima, u tomu se slučaju primjenjuju opća pravila korporativnog upravljanja.

Pravilo da uprava dioničkog društva vodi poslove društva na vlastitu odgovornost (čl. 240. st. 1.ZTD), znači da, u okviru svoje nadležnosti, uprava samostalno procjenjuje što je u najboljem interesu društva, pri čemu nije dužna slijediti upute ostalih organa ili članova društva. ${ }^{99}$ Iz toga slijedi da uprava ne mora slijediti ni upute koje bi bile povoljne za ovisno društvo. Pri ispitivanju određene upute, članovi uprave društva morali bi, naravno, primijeniti pažnju urednog i savjesnog gospodarstvenika (čl. 252. st. 1. ZTD). Sama činjenica da je odbijena uputa bila povoljna za ovisno društvo ne znači, međutim, da je uprava povrijedila dužni standard pažnje. To treba procjenjivati prema općim pravilima o odgovornosti članova uprave, uzimajući u obzir i pravilo o poslovnoj prosudbi (tzv. business judgement rule, čl. 252. st. 1. ZTD). Članovi uprave neće povrijediti dužnu pažnju ni ako odbiju uputu za koju su znali da je povoljna, ako su imala razloga vjerovati da bi, umjesto predložene, društvo trebalo poduzeti neku drugu, još povoljniju radnju. Moguće je, naravno, da odbijanjem povoljne upute članovi uprave povrijede pažnju urednog i savjesnoga gospodarstvenika što bi moglo dovesti do njihove odgovornosti za štetu. Čak ni u tom slučaju ne postoji način kojim bi glavna skupština mogla ,preventivno“ prisiliti upravu da slijedi njezinu povoljnu uputu. Isto se, na odgovarajući način, primjenjuje i na članove upravnog odbora koji samostalno vodi društvo (čl. 272.h st. 1. ZTD).

S druge strane, uprava društva s ograničenom odgovornošću vodi poslove društva u skladu s društvenim ugovorom, odlukama članova društva i obveznim uputama skupštine i nadzornog odbora, ako ga društvo ima (čl. 422. st. 2. ZTD). Budući da, kao što je već rečeno, uprava mora slijediti upute koje su štetne za društvo, uprava tim više mora provesti upute koje su neutralne ili čak povoljne za društvo. Uprava bi mogla odbiti samo upute koje su ništetne jer, primjerice, vrijeđaju propise kojima se štite vjerovnici društva ili javni interes.

Izloženo razmatranje dovodi do zaključka da je učinkovitost koja se može tražiti od upravljanja u faktičnom koncernu sasvim različita od učinkovitog upravljanja u ugovornom koncernu ili koncernu priključenih društava. U ugovornom koncernu i koncernu priključenih društava vladajuće društvo je ovlašteno posredno upravljati svim društvima koncerna kako ono smatra da je najučinkovitije za vladajuće društvo, odnosno koncern u cjelini. Ovisna društva zadržavaju vrlo ograničenu samostalnost kroz ovlasti uprave da ispita upute vladajućeg društva i odbije upute koje su nezakonite ili koje očito nisu u interesu nijednog od društava koncerna. Za razliku od toga, u faktičnom koncernu svako od društava koncerna načelno zadržava onu upravljačku samostalnost koju bi imalo da ne postoji koncern. Svrha zakonskih odredbi je zabraniti vladajućem društvu da zlouporabi svoj položaj i navede ovisno društvo na radnje

98 Altmeppen, H., op. cit. u bilj. 5, § 311, para. 466.

99 Barbić, J., Dioničko društvo, op. cit. u bilj. 32, str. 777. 
koje su štetne po ovisno društvo. Ovisno društvo, međutim, ne mora slijediti čak ni one upute vladajućeg društva koje bi bile povoljne za ovisno društva kada to ne bi proizlazilo iz općih pravila prava društava za taj pravni oblik. Ukratko rečeno, to znači da ovisno dioničko društvo nije dužno slijediti poslovodne upute vladajućeg društva, dok je ovisno društvo s ograničenom odgovornošću dužno slijediti takve upute dok god nisu ništetne.

To se može činiti čudnim ako se uzme u obzir da je za faktični koncern, kao i ostale oblike koncerna, konstitutivan pojam jedinstvenog vođenja (čl. 476. st. 1. ZTD). Ovisno dioničko društvo u faktičnom koncernu bi se, dakle, nalazilo u naizgled proturječnoj situaciji u kojoj je objedinjeno jedinstvenim vođenjem, iako njegova uprava nije dužna slijediti niti jednu uputu vladajućeg društva. Ta se proturječnost, međutim, može objasniti pomoću dvije okolnosti. Prva je da je za pojam prevladavajućeg utjecaja, na temelju kojeg se presumira koncern, dostatno da vladajuće društvo ima mehanizme kojima bi faktički moglo provoditi svoju volju čak i kada na to nije ovlašteno. Primjerice, većinski dioničar, o kojemu ovisi imenovanje nadzornog odbora (čl. 256. st. 1. ZTD) i davanje razrješnice upravi (čl. 275. st. 1. toč. 3. ZTD) ima faktičnu mogućnost izvršiti pritisak na upravu i bez da na to ima pravo. Zbog toga je, uostalom, i glavna svrha odredaba o granicama utjecaja u faktičnom koncernu zaštititi manjinske dioničare i vjerovnike ovisnoga društva.

Druga je okolnost da će upute vladajućeg društva, iako ih uprava dioničkog društva teoretski nije dužna slijediti, najčešće biti korisne za ovisno društvo. Vladajuće društvo će, naime, redovito ustrojiti koncern na način da se svako od povezanih društava specijalizira za određene aktivnosti ili određeni segment tržišta. U tom kontekstu za ovisno društvo može biti iznimno na korist „krupna slika“ kojom raspolaže vladajuće društvo. Interesi dvaju društava, osobito kada se radi o vladajućem i ovisnom društvu, nisu nužno suprotstavljeni, tako da će vrlo često ista radnja biti korisna za oba društva. Uostalom, gospodarski je pa i pravno logično razmišljanje da vladajuće društvo neće davati upute koje nisu korisne barem za koncern kao cjelinu, a time posredno zapravo bivaju korisne i za ovisno društvo. Ipak, uprava ovisnoga društva se ne bi smjela „uspavati“ i slijepo vjerovati vladajućem društvu u pogledu svake upute. Na njoj leži dužnost da prepozna koje su upute vladajućeg društva štetne po ovisno društvo i da odbije provesti, barem dok joj se vladajuće društvo ne obveže nadoknaditi štetu.

\section{ZAKLJUС̆ AK}

Dosadašnje razmatranje pokazalo je da se, neovisno o jedinstvenom vođenju kao zajedničkoj pretpostavci, pojam učinkovitog upravljanja znatno razlikuje u tri opisane vrste koncerna - ugovornom koncernu, koncernu priključenih društava i faktičnom koncernu. U ugovornom koncernu i koncernu priključenjem dolazi do značajnog „probijanja“ upravljačke samostalnosti ovisnoga društva na način da je ovisno društvo načelno dužno provoditi upute vladajućeg društva. U tim je oblicima koncerna, dakle, dominantna centripetalna tendencija. Upravi ovisnoga društva ostaje samo rezidualna funkciju prepoznavanja i odbijanja uputa koje očito ne služe interesima ni vladajućeg društva ni drugih društava koncerna niti koncernu kao cjelini u kojoj se poslovi vode 
objedinjeno (ugovorni koncern) te uputa koje su protivne zakonu (ugovorni koncern i koncern priključenih društava).

Takvo zanemarivanje upravljačke samostalnosti ovisnoga društva uravnoteženo je svojevrsnim ,probijanjem“ "neodgovornosti članova za obveze društva kao jednoga od najvažnijih načela društava kapitala. U ugovornom koncernu do toga dolazi samo zaobilazno, preko dužnosti vladajućeg društva da pokrije gubitke ovisnoga društva. U koncernu priključenih društava dolazi do izravnog probijanja prema trećima, na način da je glavno društvo solidarno odgovorno vjerovnicima priključenog društva za obveze priključenog društva. Manjinski dioničari ovisnoga društva dodatno su zaštićeni pravom na naknadu i otpremninu.

Za razliku od toga, u faktičnom koncernu načelno nastavljaju vrijediti opća pravila korporativnog upravljanja prema kojima ovisno društvo ima veću ili manju upravljačku samostalnost. Svrha koncernskih pravila o granicama utjecaja upravo je spriječiti vladajuće društvo da, iskorištavajući svoj položaj, zaobiđe ta pravila. Koncernska pravila tako konkretiziraju opće načelo lojalnosti zabranjujući vladajućem društvu da uputi ovisno društvo na poduzimanje štetnih pravnih radnji. Iznimka postoji jedino ako se vladajuće društvo do kraja poslovne godine obveže ovisnome društvu konkretno nadoknaditi štetu i ako je izgledno da će vladajuće društvo to biti u stanju učiniti. U faktičnom je koncernu, dakle, dominantna centrifugalna tendencija.

Ako bi vladajuće društvo povrijedilo svoju dužnost i dalo ovisnome dioničkom društvu štetnu uputu, uprava ovisnog društva mogla bi, dapače, morala odbiti takvu uputu. Uprava bi društva s ograničenom odgovornošću, naprotiv, bila dužna slijediti tu uputu dok god se njome ne vrijeđaju neotuđive ovlasti uprave nadzirati zakonitost poslovanja društva, osobito očuvanje njegovoga kapitala.

Iz neotuđive nadležnosti uprave dioničkog društva da vodi poslove društva proizlazi da bi uprava ovisnoga dioničkog društva mogla odbiti čak i upute koje su korisne za ovisno društvo. Ipak nije vjerojatno da će do toga u praksi često doći, među ostalim i jer bi uprava ovisnoga dioničkog društva zbog toga mogla biti odgovorna vlastitom društvu prema općim pravilima o odgovornosti uprave. S druge strane, uprava ovisnog društva s ograničenom odgovornošću ne bi mogla odbiti korisne upute, barem dok god se kreću u zakonom postavljenim granicama.

Izloženi zaključci pokazuju da se pod jedinstvenim nazivom koncerna kriju vrlo različiti upravljački modaliteti koji se više ili manje približavaju jednoj od dviju krajnosti - društvima kojima se neovisno upravlja ili potpunom upravljačkom jedinstvu. Pojednostavljeno rečeno, faktični koncern se, barem u pogledu štetnih uputa, približava neovisnim društvima, dok se ugovorni koncern i koncern priključenih društava približavaju društvima kojim se jedinstveno upravlja.

Iz perspektive vladajućeg društva za svaki od oblika koncerna postavlja se pitanje ne bi li bilo oportunije da je ovisno društvo pripojeno vladajućem društvu ili eventualno spojeno s njime u novo društvo, naravno uz uvjet da vladajuće društvo ima dostatnu većinu za donošenje takve odluke. Pripajanjem ovisnoga društva iz faktičnog koncerna vladajuće bi društvo napokon vodilo njegovo poduzeće jedinstveno s vlastitim poduzećem bez prepreka koje bi mogla postavljati uprava ovisnoga društva. Protiv pripajanja može, međutim, govoriti nekoliko razloga. Kao prvo, jedinstveno 
upravljanje nije samo povlastica nego i obveza. Uprava vladajućeg društva time bi preuzela dužnost voditi poduzeće do tada ovisnoga društva. Nadalje, vladajuće društvo bi dioničarima ovisnoga, pripojenog društva u zamjenu moralo ponuditi vlastite dionice uz eventualnu doplatu u novcu. To, među ostalim, može zahtijevati povećanje temeljnoga kapitala (čl. 519. ZTD). Na posljetku, do tada vladajuće društvo steklo bi ne samo imovinu, nego i obveze ovisnoga društva. Uostalom, time nestaju sve eventualne prednosti odvojenosti pravnih subjekata.

U odnosu na ugovorni koncern i koncern priključenih društava, imajući na umu da vladajuće društvo ionako mora angažirati svoju imovinu radi pokrivanja gubitaka ovisnoga društva, plaćanja naknade i otpremnine manjinskim dioničarima, pripajanje ili spajanje ovisnoga društva može biti prirodan korak. Pripajanju je osobito blizak koncern priključenih društava jer kod njega, kao i kod pripajanja, dolazi do istiskivanja manjinskih dioničara uz davanje primjerene otpremnine. Ako se tomu doda solidarna odgovornost vladajućeg društva za obveze priključenog društva, otpada većina argumenata za zadržavanje odvojenih pravnih osobnosti. Iz perspektive učinkovitog upravljanja pripajanje ili spajanje društava ugovornog koncerna ili koncerna priključenih društava dovodi do toga da uprava društva preuzimatelja preuzima izravno upravljanje nad pripojenim društvom, isključujući njegovu upravu kao posrednika.

Može se zaključiti da je hrvatski zakonodavac društvima ponudio široke mogućnosti izbora do kojeg će stupnja integrirati vlastito upravljanje. Ključno je, međutim, da se, nakon što se opredijele za jedan oblik, društva pridržavaju odgovarajućih pravila upravo za taj oblik. Samo se tako može postići zadovoljavajuća razina pravne sigurnosti i zaštite manjinskih članova društva i njegovih vjerovnika.

\section{LITERATURA}

Knjige i članci:

1. Altmeppen, Holger u: Goette, W.; Habersack, M. (ur.), Münchener Kommentar zum Aktienrecht, Band 5, München, C. H. Beck/Franz Vahlen, 2015., § 311-318 AktG

2. Bayer, Walter u: Goette, W.; Habersack, M. (ur.), Münchener Kommentar zum Aktienrecht, Band 1, München, C. H. Beck, 2016., § 15-19 AktG

3. Barbić, Jakša, Koncern i društva koncerna, Pravo u gospodarstvu, vol. 46, 4/2007, str. 57-94

4. Barbić, Jakša, Pravo društava, Knjiga prva, Opći dio, Zagreb, Organizator, 2008.

5. Barbić, Jakša, Pravo društava, Knjiga druga, Društva kapitala, Svezak I., Dioničko društvo, Zagreb, Organizator, 2013.

6. Barbić, Jakša, Pravo društava, Knjiga druga, Društva kapitala, Svezak II., Društvo s ograničenom odgovornošću, Zagreb, Organizator, 2013.

7. Barbić, Jakša, Pravo društava, Knjiga treća, Društva osoba, Zagreb, Organizator 2002

8. Barbić, Jakša, Vođenje poslova i upravljanje u trgovačkim društvima (povezana društva), Hrvatska gospodarska revija, vol. 45, 11/1996, str. 1574-1582

9. Bilić, Antun; Petrović, Siniša, Odgovornost članova društava u faktičnom koncernu, Zbornik Pravnog fakulteta Sveučilišta u Rijeci, vol. 39, 2/2002, str. 727-751

10. Bilić, Antun, Uzlazna sredstva osiguranja (Upstream guarantees), Zbornik 56. susreta Pravnika u gospodarstvu, Opatija 2018, Zagreb, 2018., str. 187-229.

11. Braut Filipović, Mihaela, Odgovornost društva majke za obveze društva kćeri, Zbornik 
Pravnog fakulteta Sveučilišta u Rijeci, vol. 32, 2/2011, str. 795-828

12. Ceronja, Petar, $\mathrm{O}$ odgovornosti članova nadzornog odbora ovisnog društva za štetu zbog povrede obveze nadzora tražbina iz ugovora o zajmu sklopljenih između ovisnog i vladajućeg društva, Pravo u gospodarstvu, vol. 50, 5/2011, str. 1158-1176

13. Cindori, Vladimir, Izvješće o ovisnosti trgovačkih društava s aspekta poslovanja društava, Informator, 5436/2006, str. 6-8.

14. Emmerich, Volker u: Emmerich, V.; Habersack, M.; Schürnbrand, J. (ur.), Aktien- und GmbH-Konzernrecht, München, C. H. Beck, 2016., § 15-18 AktG

15. Emmerich, Volker; Habersack, Mathias, Konzernrecht, München, C. H. Beck, 2008

16. Funatsu, Koji, Trends in European Corporate Group Law Systems and the Future of Japan's Corporate Law System, Policy Research Institute, Ministry of Finance, Japan, Public Policy Review, vol. 11, 3/2015., str. 475-483

17. Gorenc, Vilim, Povezana društva prema Zakonu o trgovačkim društvima, Računovodstvo, revizija i financije, vol. 4, 10/1994, str. 1786-1797

18. Grunewald, Barbara u: Goette, W.; Habersack, M. (ur.), Münchener Kommentar zum Aktienrecht, Band 5, München, C. H. Beck/Franz Vahlen, 2015., § 323

19. Habersack, Mathias u: Emmerich, V.; Habersack, M.; Schürnbrand, J. (ur.), Aktien- und GmbH-Konzernrecht, München, C. H. Beck, 2016., § 311-318 AktG

20. Hansen, Jesper Lau, The Report of the Reflection Group on the Future of EU Company Law-As seen from a Nordic perspective, Nordic \& European Company Law Working Paper No. 10-15, 2011, str. 17-18 (https://papers.ssrn.com/sol3/papers.cfm?abstract_ id $=1869817$ 31.3.2018.)

21. Heidinger, Andreas u: Michalski, L.; Heidinger, A.; Leible, S.; Schmidt, J. (ur.), Kommentar zum GmbHG, Band 1, München, C. H. Beck, 2017., § 30

22. Jurić, Dionis, Odgovornost vladajućeg društva za obveze ovisnog društva u hrvatskom i usporednom pravu, Zbornik Pravnog fakulteta Sveučilišta u Rijeci, vol. 23, 2/2002, str. 507-540

23. Jurić, Dionis, Transparentnost statusnih i financijskih odnosa povezanih društava, Zbornik Pravnog fakulteta Sveučilišta u Rijeci, vol. 27, 2/2006, str. 939-984

24. Koch, Jens u: Hüffer, U.; Koch, J. (ur.), Aktiengesetz, München, C. H. Beck, 2015., § 15-19, § 311-318 AktG

25. Krieger, Gerd u: Hoffmann-Becking, M. (ur.), Münchener Handbuch des Gesellschaftsrechts, Band 4, München, C. H. Beck, 2015, § 69-70

26. Ledić, Dragutin, Povezana društva - začetak hrvatskog prava koncerna, Zbornik Pravnog fakulteta Sveučilišta u Rijeci, vol. 16, 1/1995, str. 37-51

27. Merkt, Hanno u: Fleischer, H.; Goette, W. (ur.), Münchener Kommentar zum GmbHG, Band 1, München, C. H. Beck, 2018., § 13

28. Moslavac, Bruno, Pitanje odgovornosti u slučaju ovisnosti društva kada nema ugovora o vođenju poslova društva, Informator, vol. 56, 5695-5696/2008, str. 5-7

29. Müller, Hans-Friedrich u: Spindler, G.; Stilz, E. (ur.), Kommentar zum Aktienrecht, Band 2, München, C. H. Beck, 2015., § 311-318 AktG

30. Singhof, Bernd u: Spindler, G.; Stilz, E. (ur.), Kommentar zum Aktienrecht, Band 2, München, C. H. Beck, 2015., § 323

31. Spindler, Gerald u: Goette, W.; Habersack, M. (ur.), Münchener Kommentar zum Aktienrecht, Band 2, München, C. H. Beck/Franz Vahlen, 2014., § 93

32. Stengel, Arndt u: Semmler, J; Stengel, A. (ur.), Umwandlungsgesetz, München, C. H. Beck, 2017, § 2

33. Stephan, Klaus-Dieter; Tieves, Johannes u: Fleischer, H.; Goette, W. (ur.), Münchener Kommentar zum GmbHG, Band 2, München, C. H. Beck, 2016, § 37

34. Veil, Rüdiger u: Spindler, G.; Stilz, E. (ur.), Kommentar zum Aktienrecht, Band 2, München, C. H. Beck, 2015., § 308

35. Vidović, Ante, Koncern - aktualna pitanja povezivanja društava, Računovodstvo, revizija 
i financije, vol.18, 3/2008, str. 194-195.

36. Wertenbruch, Johannes u: Fleischer, H.; Goette, W. (ur.), Münchener Kommentar zum GmbHG, Band 1, München, C. H. Beck, 2016, § 47 Anh.

37. Wiesner, Georg, u: Hoffmann-Becking, M. (ur.), Münchener Handbuch des Gesellschaftsrechts, Band IV, München, C. H. Beck, 2015, § 19

38. Winner, Martin, Group Interest in European Company Law: an Overview, Acta Univ. Sapientiae, Legal Studies, vol. 5, 1/2016, str. 85-96

Pravni akti:

1. European Model Company Act (EMCA)

2. Njemački Zakon o dioničkim društvima, Aktiengesetz

3. Ustav Republike Hrvatske, NN br. 56/1990, 135/1997, 113/2000, 28/2001, 76/2010, $5 / 2014$

4. Zakon o obveznim odnosima, NN br. 35/2005, 41/2008, 125/2011, 78/2015, 29/2018

5. Zakon o trgovačkim društvima, NN br. 111/93, 34/99, 121/99, 52/00, 118/03, 107/07, $146 / 08,137 / 09,125 / 11,111 / 12,68 / 13$ i $110 / 15$

Sudska praksa:

1. VSRH Revt 159/11-2 od 24.1.2012.

2. VSRH Revt 60/04-2 od 6.10.2004.

3. VSRH Revr 344/08-2 od 17.6.2009.

4. VTS Pž-1934/06-3 od 22.4.2009.

5. VTS Pž-1760/02 od 15.4.2003.

6. VTS Pž 2859/04-3 od 6.11.2007.

7. VTS Pž 7222/04-3 od 11.10.2005.

8. VTS Pž 6097/05-3 od 29.5.2007.

9. VTS Pž 3289/2017-2 od 29.5.2017. 


\author{
Antun Bilić* \\ Siniša Petrović**
}

\author{
Summary
}

\title{
EFFECTIVE MANAGEMENT IN A GROUP OF COMAPNIES
}

The paper discusses different modalities of effective management in various types of corporate groups. The definition of a group of companies - two or more companies with a common management - presupposes a certain degree of managerial integration. On the other hand, the fact that each of the companies retains its own legal personality suggests at least a partial managerial independence. Therefore, the limits of mutual influence of companies that belong to the same group are determined by opposing centrifugal and centripetal forces. The law of group of companies has to precisely define those limits and to place them at disposal to entrepreneurs. It will be demonstrated that those limits are not the same for all types fo corporate groups. The paper analyses three types of corporate group between a parent and a subsidiary company - contractual group of companies, group of integrated companies and factual (de facto) group of companies.

Keywords: effective management; management board; contractual group of companies; group of integrated companies; factual (de facto) group of companies; parent company; subsidiary company.

\section{Zussamenfassung}

\section{WIRKSAMES KONZERNMANAGEMENT}

Dieser Beitrag bespricht die Modalitäten eines wirksamen Managements in unterschiedlichen Konzernformen. Selbst die Definition des Konzerns, die besagt, dass der Konzern den Zusammenschluss mehrerer Unternehmen unter einheitlicher Leitung darstellt, impliziert einen bestimmten Grad der Managementintegration. Andererseits weist der Umstand, dass jedes der Unternehmen die eigene Rechtspersönlichkeit behält, wenigstens auf eine partielle Unabhängigkeit des Managements hin. Die Grenzen des gegenseitigen Einflusses von Unternehmen in einem Konzern sind deswegen durch entgegengesetzte zentrifugale und zentripetale Kräfte bestimmt. Das Recht der verbundenen Unternehmen muss diese Grenzen klar definieren und sie den Unternehmern zur Verfügung stellen, so dass die Unternehmer diese Grenzen gemäß

\footnotetext{
* Antun Bilić, Ph.D., Assistant Professor, University of Zagreb, Faculty of Law; abilic@pravo.hr.

** Siniša Petrović, Ph.D., Full Professor, University of Zagreb, Faculty of Law; sinisa.petrovic@ pravo.hr.
} 
ihren Bedürfnissen ausnutzen können. Wie es in diesem Beitrag gezeigt wird, sind diese Grenzen nicht für alle Konzerne gleich. Der Beitrag bespricht detaillierter drei Formen des aus dem herrschenden und dem abhängigen Unternehmen bestehenden Konzerns: den Vertragskonzern, den Eingliederungskonzern und den faktischen Konzern.

Schlüsselwörter: wirksames Management; Verwaltung; Vertragskonzern; Eingliederungskonzern; faktischer Konzern; herrschendes und abhängiges Unternehmen.

\section{Riassunto}

\section{GESTIONE EFFICIENTE DEL GRUPPO}

Nel lavoro di disaminano le modalità di gestione efficiente nelle diverse forme di gruppi societari. La definizione stessa di gruppo, quale insieme di società riunite sotto la stessa gestione, presuppone un determinato grado di integrazione nell'amministrazione. D'altra parte, la circostanza che ciascuna delle società mantenga la propria personalità giuridica suggerisce una perlomeno parziale autonomia gestionale. I confini dell'influenza reciproca delle società del gruppo sono, pertanto, determinate dalla contrapposizione di forze centrifughe e centripete. Sta, dunque, alla disciplina giuridica delle società collegate definire chiaramente tali confini e porli a disposizione degli imprenditori, al fine del migliore uso possibile a seconda delle loro esigenze. Come si dimostrerà, tali confini non sono gli stessi per ogni tipo di gruppo societario. Nel lavoro si esaminano in maniera dettagliata tre forme di gruppo di società dominante e dipendente - il gruppo contrattuale, il gruppo di società annesse ed il gruppo di fatto.

Parole chiave: gestione efficiente; amministrazione; gruppo contrattuale; gruppo di società annesse; gruppo di fatto; società dominante e dipendente. 
